\section{OPEN ACCESS}

Edited by:

Susan Hua

University of Newcastle, Australia

Reviewed by:

James Hainfeld,

Nanoprobes, United States

Arkadiusz Jozefczak

Adam Mickiewicz University in

Poznan, Poland

*Correspondence:

Maria Kavallaris

m.kavallaris@ccia.unsw.edu.au

Specialty section

This article was submitted to Pharmaceutical Medicine and

Outcomes Research,

a section of the journal

Frontiers in Pharmacology

Received: 16 April 2018

Accepted: 10 July 2018

Published: 02 August 2018

Citation:

Chang D, Lim M, Goos JACM, Qiao R, Ng YY, Mansfeld FM, Jackson M, Davis TP and Kavallaris $M$ (2018) Biologically Targeted Magnetic Hyperthermia: Potential and Limitations. Front. Pharmacol. 9:831. doi: 10.3389/fphar.2018.00831

\title{
Biologically Targeted Magnetic Hyperthermia: Potential and Limitations
}

\begin{abstract}
David Chang ${ }^{1,2,3}$, May Lim ${ }^{4}$, Jeroen A. C. M. Goos ${ }^{5,6}$, Ruirui Qiao ${ }^{5}$, Yun Yee $\mathrm{Ng}^{4}$, Friederike M. Mansfeld ${ }^{1,3,5}$, Michael Jackson ${ }^{2}$, Thomas P. Davis ${ }^{5,7}$ and Maria Kavallaris ${ }^{1,3 *}$

${ }^{1}$ Children's Cancer Institute, Lowy Cancer Research Centre, University of New South Wales, Sydney, NSW, Australia, 2 Department of Radiation Oncology, Nelune Comprehensive Cancer Centre, Prince of Wales Hospital, Sydney, NSW, Australia, ${ }^{3}$ ARC Centre of Excellence in Convergent Bio-Nano Science and Technology and Australian Centre for Nanomedicine, University of New South Wales, Sydney, NSW, Australia, ${ }^{4}$ School of Chemical Engineering, University of New South Wales, Sydney, NSW, Australia, ${ }^{5}$ ARC Centre of Excellence in Convergent Bio-Nano Science and Technology, Monash Institute of Pharmaceutical Sciences, Monash University, Melbourne, VIC, Australia, ${ }^{6}$ Department of Radiology, Memorial Sloan Kettering Cancer Center, New York, NY, United States, ${ }^{7}$ Department of Chemistry, University of Warwick, Coventry, United Kingdom
\end{abstract}

Hyperthermia, the mild elevation of temperature to $40-43^{\circ} \mathrm{C}$, can induce cancer cell death and enhance the effects of radiotherapy and chemotherapy. However, achievement of its full potential as a clinically relevant treatment modality has been restricted by its inability to effectively and preferentially heat malignant cells. The limited spatial resolution may be circumvented by the intravenous administration of cancer-targeting magnetic nanoparticles that accumulate in the tumor, followed by the application of an alternating magnetic field to raise the temperature of the nanoparticles located in the tumor tissue. This targeted approach enables preferential heating of malignant cancer cells whilst sparing the surrounding normal tissue, potentially improving the effectiveness and safety of hyperthermia. Despite promising results in preclinical studies, there are numerous challenges that must be addressed before this technique can progress to the clinic. This review discusses these challenges and highlights the current understanding of targeted magnetic hyperthermia.

Keywords: magnetic hyperthermia, targeted therapy, iron oxide nanoparticles, cancer therapy, magnetic nanoparticles

\section{INTRODUCTION}

Hyperthermia, a treatment aimed at raising the temperature of cancerous regions of the body to $40-43^{\circ} \mathrm{C}$, can induce cancer cell death by enhancing the cytotoxic effects of radiotherapy and chemotherapy (Wust et al., 2002). Extensive preclinical and clinical research into the application of hyperthermia has been conducted, with a number of randomized trials demonstrating that, when combined with radiotherapy, it has the potential to improve the outcomes of various cancers without significantly increasing toxicity (De Haas-Kock et al., 2009; Lutgens et al., 2010). Despite these promising results, hyperthermia is rarely incorporated into modern oncological management due to its ineffectiveness when applied as a single modality treatment and a lack of large phase 3 clinical trials combining hyperthermia with both standard chemotherapy and radiotherapy (van der Zee, 2002). Furthermore, a major disadvantage of conventional hyperthermia is that, in general, both malignant and non-malignant cells are equally sensitive to heating (Dewey et al., 1977; Roizin-Towle and Pirro, 1991). This is in contrast to chemotherapy or radiotherapy, which are 
generally more cytotoxic toward malignant cells. As a result, there has been significant interest in the concept of "biologically targeted magnetic hyperthermia," whereby targeted magnetic iron oxide nanoparticles (MIONs) are administered intravenously in order to heat tumors under an alternating magnetic field. In this review, we will discuss the current understanding of targeted magnetic hyperthermia and the limitations that must be overcome for further progression into clinical practice.

\section{HYPERTHERMIA AND CELL DEATH}

Hyperthermia can cause cell death through a range of different mechanisms and there are no consistent differences in thermal sensitivities between malignant and non-malignant cells (Dewey et al., 1977; Roizin-Towle and Pirro, 1991). It has been shown in vitro that cell viability following hyperthermia treatment is heavily influenced by both the temperature and the duration of hyperthermia (Figure 1). Even half a degree rise in temperature can have a substantial impact on cell viability, highlighting the importance of effective and homogenous delivery of hyperthermia (Dewey et al., 1977). One of the possible mechanisms behind the reduction in cell viability is protein denaturation with subsequent activation and deactivation of several downstream pathways (van der Zee, 2002; Wust et al., 2002). Individual proteins have specific temperature thresholds for denaturation, with highly expressed proteins generally being more tolerant to heat (Leuenberger et al., 2017). Protein denaturation occurs from approximately $40^{\circ} \mathrm{C}$ and higher temperatures will denature a greater proportion of proteins, which may explain why the rate of cell death rises with the temperature (Lepock, 2005b). At temperatures of $40-42^{\circ} \mathrm{C}$, only a small fraction of proteins is denatured, however, some of these can subsequently co-aggregate with native proteins, thereby significantly increasing the level of aggregation (Borrelli et al., 1996). It is this combination of heat-induced denaturation and subsequent co-aggregation that is thought to affect several downstream pathways including inactivation of protein synthesis, cell cycle progression and DNA repair (Dewey et al., 1977; Kampinga et al., 2004; Lepock, 2005a). Furthermore, possibly through a mechanism that is unrelated to protein denaturation, hyperthermia can have an adverse impact on the cytoskeleton, organelles, intracellular transport, and RNA processing (Richter et al., 2010). Another potential contributor to reduction in cell viability is heat-induced alterations in the plasma and subcellular organelle membranes, as well as membrane proteins (Richter et al., 2010; Mello et al., 2017).

Sufficient application of hyperthermia can result in cell death (Figure 1), but if cells survive several major classes of proteins will be activated leading to thermotolerance. These classes of proteins include: heat shock proteins that stabilize misfolded proteins, proteolytic enzymes that clear denatured/aggregated proteins, RNA-, and DNA-modifying proteins that repair damage, and others (Richter et al., 2010).

In addition to the responses to hyperthermia at a cellular level described above, hyperthermia may impart its effects via several additional, unique mechanisms on cell communities and these have been investigated in vivo. Tumors are generally associated with hypoxic and acidic environments due to poor vasculature, conditions in which cells are known to be more susceptible to hyperthermia (Gerweck et al., 1979; Eales et al., 2016). Elevated temperatures can lead to increased perfusion within the tumor, leading to greater chemotherapeutic drug delivery and higher oxygen concentrations, which in turn can sensitize tumors to radiotherapy (Song et al., 1996; Rau et al., 2000). Hyperthermia may enhance the immune response via several mechanisms, including increased migration of immune effector cells to the tumor, modulation of cell surface molecules and various pro-inflammatory cytokines, proliferation of effector cells, and increased immune cell cytotoxicity against malignant cells (Peer et al., 2010).

Despite the multitude of mechanisms by which hyperthermia can induce cell death, it is not efficient as a single agent treatment, mainly due to its poor specificity and the development of thermotolerance which may make subsequent hyperthermia treatments less effective. However, in combination with radiotherapy or chemotherapy, hyperthermia can lead to improved patient outcomes.

\section{HYPERTHERMIA IN COMBINATION WITH RADIOTHERAPY AND CHEMOTHERAPY}

In the clinic, hyperthermia can be applied to a local area, a specific region of the body or the entire body. In the past few decades, mild elevations of temperature have been achieved by various means including thermal chambers, hot water blankets, application of electromagnetic energy, perfusion of limb or body cavity with heated fluids, ultrasound and MIONs (van der Zee, 2002; Wust et al., 2002). In order to improve the efficacy, hyperthermia has often been evaluated as an adjunct treatment to enhance radiotherapy and cytotoxic chemotherapy. One way of expressing the enhancement of radiotherapy or chemotherapy is via the thermal enhancement ratio (TER), where TER is the ratio of the dose of radiation or drug alone that is required to achieve the end point to the dose of radiation or drug combined with heat to achieve the same end point (Overgaard, 1984). As an example, $60 \mathrm{~min}$ of hyperthermia at $42^{\circ} \mathrm{C}$, can result in a TER of nearly 2 for radiotherapy, making hyperthermia one of the most potent radiosensitizers (Overgaard, 1984). Hyperthermia is thought to enhance radiotherapy via protein denaturation and the subsequent inactivation of proteins involved in DNA repair. Inactivation of DNA repair proteins, particularly those involved in excision of clustered base damage, may prevent repair of the DNA damage induced by radiotherapy, leading to increased cell death (Kampinga and Dikomey, 2001). In vivo, hyperthermia can prime the tumor to radiotherapy via increased vascular perfusion and oxygenation of previously radioresistant, hypoxic areas (Song et al., 2005). Both preclinical and clinical evidence indicates that the TER is highest when hyperthermia is delivered simultaneously or in close temporal proximity to radiotherapy when protein denaturation and aggregation are likely to be at their greatest (van Leeuwen et al., 2017). Furthermore, the 


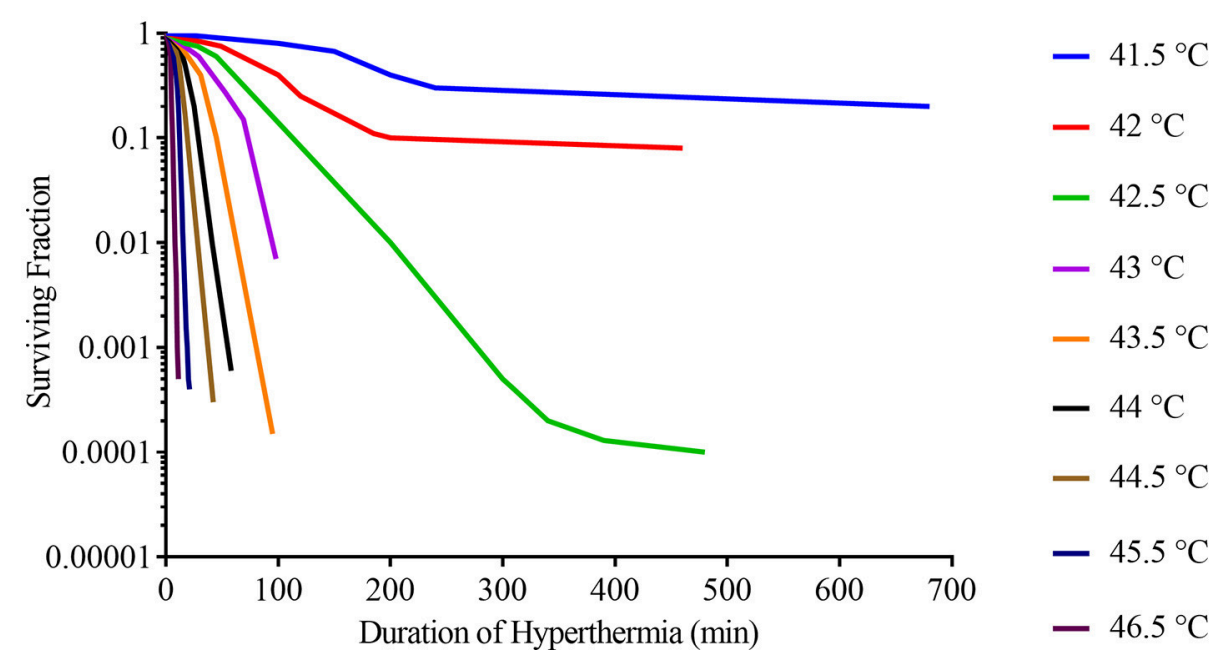

FIGURE 1 | Survival curves for asynchronous Chinese hamster ovary (CHO) cells heated at different temperatures for varying lengths of time. Adapted from Dewey et al. (1977).

TER increases with temperature and duration of hyperthermia (Overgaard, 1984).

Hyperthermia can synergistically enhance the efficacy of numerous chemotherapeutic agents including cisplatin, cyclophosphamide and bleomycin, whilst no significant enhancement for 5-fluorouracil, doxorubicin, and vincristine has been observed. For example, the application of $30 \mathrm{~min}$ of hyperthermia at $41.5^{\circ} \mathrm{C}$ in vivo, can result in a TER of 1.48 for cisplatin and 2.28 for cyclophosphamide (Urano et al., 1999). Although the exact mechanism for chemosensitization is poorly understood, for alkylating or alkylating-like platinum agents like cyclophosphamide and cisplatin, their ability to interact with and encourage protein denaturation may be partly responsible (Lepock, 2005b). In vivo, hyperthermia can lead to chemosensitivity via increased tumor blood flow and increased vascular permeability resulting in increased accumulation of chemotherapeutic agent (Song et al., 2005).

There have been a number of randomized clinical trials on the impact of hyperthermia on various cancers in combination with radiotherapy or chemotherapy or both (Tables 1-3), with many other studies currently in progress (Valdagni et al., 1988; Berdov and Menteshashvili, 1990; Datta et al., 1990; Sharma et al., 1991; Sugimachi et al., 1994; Kitamura et al., 1995; Overgaard et al., 1996; Vernon et al., 1996; Sneed et al., 1998; Harima et al., 2001; van der Zee, 2002; Jones et al., 2005; Franckena et al., 2008; Verwaal et al., 2008; Huilgol et al., 2010; Issels et al., 2010; Colombo et al., 2011; Cihoric et al., 2015; Arends et al., 2016). The majority of studies demonstrated higher rates of local response with only mild to moderate toxicities. It is worth noting that there is some heterogeneity in the outcomes, which may be due to differences in heating protocols. An area of deficiency, and perhaps one of the reasons why hyperthermia is rarely used in the clinic is that delivering sufficient hyperthermia to the tumor, whilst sparing the surrounding normal tissue, is difficult.

\section{MAGNETIC HYPERTHERMIA}

Despite the ability of hyperthermia to enhance radio- and chemotherapy treatments, toxicity due to the similar responses of malignant, and healthy tissues to hyperthermia remains a barrier to clinical application. A promising approach to overcoming this obstacle is magnetic hyperthermia, a form of hyperthermia that is currently undergoing clinical trials. It was first proposed by Gilchrist et al. (1957), who introduced the concept of injecting MIONs (20-100 nm), into lymphatic channels in order to heat residual cancer cells under an Alternating Magnetic Field (AMF) (Gilchrist et al., 1957). In 1993, Jordan et al. showed that delivering magnetic nanoparticles via direct injection into the tumor could result in much more effective and selective heating of tumors when compared to other heating techniques such as radiofrequency heating and ultrasound (Jordan et al., 1993). Furthermore, there is in vitro evidence that certain types of cancers including glioblastoma cells can take up magnetic nanoparticles more efficiently than non-malignant cells, although the exact mechanism is not well understood (Jordan et al., 1999). Since then, significant efforts have gone into the development of a clinical AMF system, resulting in the formation of a publicly listed company, MagForce AG based in Germany. The company has developed NanoTherm ${ }^{\circledR}$ aminosilane coated ferrofluid, NanoActivator ${ }^{\circledR}$ alternating magnetic field applicator, and NanoPlan ${ }^{\circledR}$ temperature simulation software.

In the past 2 decades, phase 1 , and 2 clinical studies of intratumorally delivered magnetic nanoparticles and the subsequent application of AMF via the MagForce system have been successfully conducted for patients with glioblastoma and prostate cancers (Johannsen et al., 2005, 2007a,b; MaierHauff et al., 2011). Phase 1 clinical studies on patients with prostate cancer demonstrated the feasibility of the approach with no significant late treatment-related morbidity. The average temperatures achieved were in the hyperthermic 
TABLE 1 | List of randomized clinical trials on hyperthermia combined with radiotherapy.

\begin{tabular}{|c|c|c|c|c|c|}
\hline Reference & Cancer type & $\begin{array}{l}\text { Number of } \\
\text { patients } \\
\text { randomized }\end{array}$ & Type of treatment & Outcomes & $\begin{array}{l}\text { Toxicity from } \\
\text { hyperthermia }\end{array}$ \\
\hline $\begin{array}{l}\text { Valdagni et al., } \\
1988\end{array}$ & $\begin{array}{l}\text { Fixed and inoperable N3 } \\
\text { cervical nodal squamous } \\
\text { cell carcinoma } \\
\text { metastases from either a } \\
\text { previous, concomitant } \\
\text { T1-T3 head and neck } \\
\text { primary or unknown } \\
\text { primary }\end{array}$ & 44 nodes & $\begin{array}{l}\text { Control arm: Radiotherapy } \\
\text { Experimental arm: Radiotherapy }+ \\
\text { hyperthermia (radiative } \\
\text { hyperthermia, } 280-300 \mathrm{MHz} \text { within } \\
20-25 \mathrm{~min} \text { of irradiation, } \geq 42.5^{\circ} \mathrm{C} \\
\text { for } 30 \mathrm{~min}, 2-6 \text { treatments) }\end{array}$ & $\begin{array}{l}\text { Complete response rates: } \\
82.3 \% \text { for experimental arm } \\
\text { and } 36.8 \% \text { for control arm } \\
p=0.0152 \\
\text { Thermal enhancement ratio } \\
=2.23\end{array}$ & $\begin{array}{l}\text { Similar acute toxicities } \\
\text { between control and } \\
\text { experimental arm }\end{array}$ \\
\hline $\begin{array}{l}\text { Datta et al., } \\
1990\end{array}$ & $\begin{array}{l}\text { Head and neck } \\
\text { carcinoma Stage I-IV }\end{array}$ & 65 & $\begin{array}{l}\text { Control arm: Radiotherapy } \\
\text { Experimental arm: Radiotherapy + } \\
\text { hyperthermia (capacitive } \\
\text { hyperthermia, } 27.12 \mathrm{MHz} \text {, } \\
\text { immediately before radiotherapy, } \\
\geq 42.5^{\circ} \mathrm{C} \text { for } 20 \mathrm{~min} \text {, twice a week) }\end{array}$ & $\begin{array}{l}\text { At } 18 \text { months post } \\
\text { treatment, } 19 \% \text { disease free } \\
\text { survival for control and } 33 \% \\
\text { for experimental arm } p= \\
0.11 \text { For stages III and IV, } \\
\text { control } 8 \% \text {, experimental } \\
25 \% p=0.03,79 \% \text { of } \\
\text { study group had almost } \\
\text { complete alleviation of pain } \\
\text { compared to only } 50 \% \text { of } \\
\text { control group } p<0.02\end{array}$ & $\begin{array}{l}3 \text { of } 33 \text { patients in the } \\
\text { experimental arm } \\
\text { developed local } \\
\text { erythema and facial } \\
\text { edema }\end{array}$ \\
\hline $\begin{array}{l}\text { Berdov and } \\
\text { Menteshashvili, } \\
1990\end{array}$ & $\begin{array}{l}\text { T4N0M0 Rectal } \\
\text { carcinoma }\end{array}$ & 115 & $\begin{array}{l}\text { Control arm: Pre-operative } \\
\text { radiotherapy } \\
\text { Experimental arm: Pre-operative } \\
\text { radiotherapy and hyperthermia } \\
\text { (capacitive hyperthermia involving } \\
\text { an endorectal antenna, } 915 \mathrm{MHz} \text {, } \\
42-43^{\circ} \mathrm{C} \text { for } 1 \mathrm{~h}, 4-5 \text { treatments, } \\
\text { radiation delivered within } 10 \mathrm{~min} \text { ) }\end{array}$ & $\begin{array}{l}55.4 \% \text { of experimental arm } \\
\text { were able to have an } \\
\text { operation compared to } \\
27.1 \% \text { for control arm } \\
5 \text { year survival } 35.6 \% \text { for } \\
\text { experimental arm compared } \\
\text { to } 6.6 \% \text { for control group } \\
p<0.05\end{array}$ & $\begin{array}{l}\text { Comparable } \\
\text { post-operative } \\
\text { complications between } \\
\text { control and } \\
\text { experimental arm }\end{array}$ \\
\hline $\begin{array}{l}\text { Sharma et al., } \\
1991\end{array}$ & $\begin{array}{l}\text { Stage II and III Cervical } \\
\text { Carcinoma }\end{array}$ & 50 & $\begin{array}{l}\text { Control arm: Radiotherapy } \\
\text { Experimental arm: Radiotherapy + } \\
\text { hyperthermia (capacitive } \\
\text { hyperthermia involving an } \\
\text { intravaginal electrode, } 27.12 \mathrm{MHz} \text {, } \\
42-43^{\circ} \mathrm{C} \text { for } 30 \mathrm{~min} \text {, radiation } \\
\text { delivered within } 30 \text { min, } 3 \text { times per } \\
\text { week for } 4 \text { weeks) }\end{array}$ & $\begin{array}{l}18 \text { months of follow-up } \\
\text { Local control } 50 \% \text { for } \\
\text { control arm } \\
70 \% \text { for experimental arm } \\
p<0.05\end{array}$ & $\begin{array}{l}\text { No major toxicity from } \\
\text { hyperthermia }\end{array}$ \\
\hline $\begin{array}{l}\text { Perez et al., } \\
1991\end{array}$ & Superficial Tumors & 245 & $\begin{array}{l}\text { Control arm: Radiotherapy } \\
\text { Experimental arm: Radiotherapy }+ \\
\text { hyperthermia (radiative } \\
\text { hyperthermia, } 915 \mathrm{MHz}, 43^{\circ} \mathrm{C} \text { for } \\
60 \text { min immediately after } \\
\text { irradiation, } 8 \text { treatments) }\end{array}$ & $\begin{array}{l}\text { Improved local control for } \\
\text { tumors }<3 \mathrm{~cm} \text { but not for } \\
\text { tumors }>3 \mathrm{~cm}\end{array}$ & $\begin{array}{l}30 \% \text { incidence of } \\
\text { thermal blisters in the } \\
\text { experimental arm }\end{array}$ \\
\hline $\begin{array}{l}\text { Vernon et al., } \\
1996^{\star}\end{array}$ & $\begin{array}{l}\text { Patients with advanced } \\
\text { primary or recurrent } \\
\text { breast cancer having } \\
\text { local radiotherapy rather } \\
\text { than surgery }\end{array}$ & 306 & $\begin{array}{l}\text { Control arm: Radiotherapy } \\
\text { Experimental arm: Radiotherapy }+ \\
\text { hyperthermia (via various devices } \\
\text { and frequencies depending on the } \\
\text { study location, } \geq 42.5^{\circ} \mathrm{C} \text { for } \\
\geq 30 \text { min, various intervals between } \\
\text { radiotherapy and hyperthermia, } \\
2-8 \text { treatments) }\end{array}$ & $\begin{array}{l}\text { Complete response for the } \\
\text { control arm } 41 \% \\
59 \% \text { for hyperthermia arm } \\
p<0.001 \\
\text { Greatest difference seen in } \\
\text { patients with recurrent } \\
\text { lesions in previously } \\
\text { irradiated areas, where } \\
\text { further irradiation was } \\
\text { limited to low dose }\end{array}$ & $\begin{array}{l}\text { More acute toxicities in } \\
\text { the experimental arm: } \\
\text { Blisters: } 11 \% \text { vs. } 2 \% \\
\text { Ulceration } \\
7 \% \text { vs. } 2 \% \\
\text { Necrosis } \\
7 \% \text { vs. } 1 \% \\
\text { Comparable rates of } \\
\text { late toxicity between } \\
\text { the control and } \\
\text { experimental arm }\end{array}$ \\
\hline $\begin{array}{l}\text { Overgaard } \\
\text { et al., } 1996\end{array}$ & $\begin{array}{l}\text { Recurrent or metastatic } \\
\text { malignant melanoma }\end{array}$ & $\begin{array}{c}134 \text { lesions in } 70 \\
\text { patients }\end{array}$ & $\begin{array}{l}\text { Control arm: Radiotherapy } \\
\text { Experimental arm: Radiotherapy }+ \\
\text { hyperthermia (variable mode of } \\
\text { delivery, hyperthermia delivered } \\
\text { within } 30 \text { min of radiotherapy, } \\
\text { aimed for }>60 \text { equivalent minutes } \\
\text { of } 43^{\circ} \mathrm{C} \text { but in reality only a median } \\
\text { of } 9 \text { equivalent minutes of } 43^{\circ} \mathrm{C} \\
\text { achieved, } 3 \text { treatments) }\end{array}$ & $\begin{array}{l}\text { Complete response rate } \\
62 \% \text { for experimental arm } \\
\text { and } 35 \% \text { for radiotherapy } \\
\text { only control arm } \\
p=0.003\end{array}$ & $\begin{array}{l}\text { Similar acute or late } \\
\text { radiation reactions in } \\
\text { control and } \\
\text { experimental arm }\end{array}$ \\
\hline
\end{tabular}


TABLE 1 | Continued

\begin{tabular}{|c|c|c|c|c|c|}
\hline Reference & Cancer type & $\begin{array}{l}\text { Number of } \\
\text { patients } \\
\text { randomized }\end{array}$ & Type of treatment & Outcomes & $\begin{array}{l}\text { Toxicity from } \\
\text { hyperthermia }\end{array}$ \\
\hline $\begin{array}{l}\text { Emami et al., } \\
1996\end{array}$ & $\begin{array}{l}\text { Persistent or recurrent } \\
\text { tumors after previous } \\
\text { radiotherapy and/or } \\
\text { surgery, amenable to } \\
\text { interstitial radiotherapy }\end{array}$ & 171 & $\begin{array}{l}\text { Control arm: Interstitial } \\
\text { radiotherapy } \\
\text { Experimental arm: Interstitial } \\
\text { radiotherapy + hyperthermia } \\
\text { (delivered by either } 300-2450 \mathrm{MHz} \\
\text { microwave antennas or } 0.1-1 \mathrm{MHz} \\
\text { radiofrequency currents, } \geq 43^{\circ} \mathrm{C} \\
\text { for } 60 \text { min, hyperthermia delivered } \\
\text { within } 60 \text { min of irradiation, } 1-2 \\
\text { sessions) }\end{array}$ & $\begin{array}{l}\text { No difference in survival or } \\
\text { complete response. }\end{array}$ & $\begin{array}{l}\text { Similar toxicity between } \\
\text { control and } \\
\text { experimental arm }\end{array}$ \\
\hline $\begin{array}{l}\text { Van Der Zee } \\
\text { et al., } 2000\end{array}$ & $\begin{array}{l}\text { Muscle-invasive } \\
\text { bladder cancer } \\
\text { (including T2, T3, T4, } \\
\text { N0, M0) Cervical } \\
\text { Cancer Stages IIB, IIIB } \\
\text { or IV Rectal Cancer } \\
\text { Stage M0-M1 }\end{array}$ & 361 & $\begin{array}{l}\text { Control arm: Radiotherapy } \\
\text { Experimental arm: Radiotherapy }+ \\
\text { hyperthermia (delivered using } \\
\text { various systems, } 42^{\circ} \mathrm{C} \text { for } 60 \mathrm{~min} \text {, } \\
\text { within } 1-4 \mathrm{~h} \text { after radiotherapy, } 5 \\
\text { treatments) }\end{array}$ & $\begin{array}{l}\text { Complete response rates: } \\
\text { 39\% control arm } \\
55 \% \text { experimental arm } \\
p<0.001 \\
\text { Lower local failure rate for } \\
\text { hyperthermia arm: (relative } \\
\text { hazard ratio 0.76) } \\
p=0.04 \\
\text { At } 3 \text { years, no significant } \\
\text { difference in overall survival } \\
\text { except for cervical cancer } \\
(51 \% \text { and } 27 \% \\
p=0.009 \text { ) }\end{array}$ & $\begin{array}{l}\text { Cases of burns in the } \\
\text { experimental arm } \\
\text { Similar rates of late } \\
\text { radiation toxic effects } \\
\text { between control and } \\
\text { experimental arm }\end{array}$ \\
\hline $\begin{array}{l}\text { Harima et al., } \\
2001\end{array}$ & $\begin{array}{l}\text { Stage IIIB cervical } \\
\text { carcinoma }\end{array}$ & 40 & $\begin{array}{l}\text { Control arm: External beam } \\
\text { radiotherapy + high dose rate } \\
\text { intracavitary brachytherapy } \\
\text { Experimental arm: External beam } \\
\text { radiotherapy + high dose rate } \\
\text { intracavitary brachytherapy + } \\
\text { hyperthermia (capacitive heating } \\
\text { device, } 8 \mathrm{MHz} \text {, delivered within } \\
30 \text { min of radiotherapy, for a total } \\
\text { of } 60 \text { min, average temperature of } \\
40.6^{\circ} \mathrm{C} \text { achieved, } 3 \text { sessions) }\end{array}$ & $\begin{array}{l}\text { Significant difference in } \\
\text { 3-year local relapse-free } \\
\text { survival } \\
48.5 \% \text { control arm } \\
79.7 \% \text { experimental arm } \\
p=0.048 \\
\text { No significant improvement } \\
\text { in 3-year overall survival and } \\
\text { disease-free survival }\end{array}$ & $\begin{array}{l}\text { Similar rates of acute or } \\
\text { late toxicity between } \\
\text { the control and } \\
\text { experimental arm }\end{array}$ \\
\hline $\begin{array}{l}\text { Jones et al., } \\
2005\end{array}$ & $\begin{array}{l}\text { Malignancy } \leq 3 \mathrm{~cm} \text { in } \\
\text { thickness from the } \\
\text { body surface }\end{array}$ & 109 & $\begin{array}{l}\text { All patients received hyperthermia } \\
\text { (radiative hyperthermia, } 433 \mathrm{MHz} \text {, } \\
\text { for } \leq 1 \mathrm{~h} \text { maximum allowable } \\
\text { temperature of normal tissue } \\
43^{\circ} \mathrm{C} \text { ) for } 1 \mathrm{~h} \text {. If they were unable } \\
\text { to achieve a thermal dose of } \geq 0.5 \\
\mathrm{CEM} 43^{\circ} \mathrm{C} \text { T90, they were not } \\
\text { randomized. } \\
\text { Rest of patients were then } \\
\text { randomized. } \\
\text { Control: No further hyperthermia } \\
\text { but had radiotherapy } \\
\text { Experimental: Hyperthermia }+ \\
\text { radiotherapy (twice a week, } 1-2 \mathrm{~h} \text {, } \\
\text { targeted between } 10-100 \\
\text { cumulative equivalent minutes at } \\
43^{\circ} \mathrm{C} \text { T90) }\end{array}$ & $\begin{array}{l}\text { Complete response rate: } \\
\text { Hyperthermia arm } 66 \% \\
\text { Control arm } 42 \% \\
p=0.02 \\
\text { Note that some patients } \\
\text { received systemic treatment } \\
\text { but there was no significant } \\
\text { difference in the proportion } \\
\text { of patients in each arm who } \\
\text { received systemic therapy } \\
\text { No significant difference in } \\
\text { overall survival }\end{array}$ & $\begin{array}{l}\text { Grade } 1 \text { and } 2 \text { thermal } \\
\text { burns } 41 \% \text { in } \\
\text { experimental arm } \\
4 \% \text { in control arm } \\
\text { Grade } 3 \text { thermal burns } \\
5 \% \text { for experimental } \\
\text { arm } \\
2 \% \text { in control arm } \\
11 \% \text { catheter (used to } \\
\text { monitor the } \\
\text { temperature) related } \\
\text { side effects for } \\
\text { experimental arm } \\
2 \% \text { for control arm }\end{array}$ \\
\hline $\begin{array}{l}\text { Franckena } \\
\text { et al., } 2008\end{array}$ & $\begin{array}{l}\text { Locoregionally } \\
\text { advanced cervical } \\
\text { cancer }\end{array}$ & 114 & $\begin{array}{l}\text { Control arm: Radiotherapy } \\
\text { Experimental arm: Radiotherapy }+ \\
\text { hyperthermia (via various systems } \\
\text { depending on site, }>42^{\circ} \mathrm{C} \text { for } \\
60 \text { min, } 5 \text { treatments) }\end{array}$ & $\begin{array}{l}12 \text { year follow-up } \\
\text { Local control: } \\
37 \% \text { for hyperthermia arm } \\
56 \% \text { for control } \\
p=0.01\end{array}$ & $\begin{array}{l}\text { Similar rates of late } \\
\text { toxicity between control } \\
\text { and experimental arm }\end{array}$ \\
\hline
\end{tabular}


TABLE 1 | Continued

\begin{tabular}{|c|c|c|c|c|c|}
\hline Reference & Cancer type & $\begin{array}{l}\text { Number of } \\
\text { patients } \\
\text { randomized }\end{array}$ & Type of treatment & Outcomes & $\begin{array}{l}\text { Toxicity from } \\
\text { hyperthermia }\end{array}$ \\
\hline
\end{tabular}

*Meta-analysis of 5 randomized trials. The 5 trials were not published separately due to slow accrual.

range $\left(40-43^{\circ} \mathrm{C}\right)$, as opposed to the thermoablative range $\left(>50^{\circ} \mathrm{C}\right)$. Although there were PSA declines following magnetic hyperthermia, responses in the monotherapy trial were of limited extent and duration and therefore, a phase 2 trial is now recruiting patients with intermediate risk prostate cancer and is evaluating magnetic hyperthermia in combination with low dose rate brachytherapy (Johannsen et al., 2010). Furthermore, MagForce has recently received an Investigational Device Exemption (IDE) for use in patients with intermediate prostate cancer undergoing active surveillance. Recruitment of patients with intermediate risk prostate cancer will commence after approval by ethics committees (Magforce, 2013, 2018). It is hoped that hyperthermia treatment in such patients can control the more aggressive component of the tumor and prevent or delay the need for radiotherapy or surgery. A phase 2 clinical trial involving 66 patients with recurrent glioblastoma, demonstrated a median overall survival of 13.4 months from the time of tumor recurrence (Maier-Hauff et al., 2011). Acute toxicities observed in this study included tachycardia (18.2\%), headaches (13.6\%), motor disturbances (21.2\%), and convulsions (22.7\%), which may be prevented with anti-epileptic drugs. In the magnetic hyperthermia study, however, no prolonged side effects were observed other than worsening motor disturbances, which may be related to disease progression rather than magnetic hyperthermia (Maier-Hauff et al., 2011). Following the phase 2 clinical trial, MagForce has been conducting a randomized, controlled trial (DRKS00005476) to determine the efficacy and safety of NanoTherm ${ }^{\circledR}$ monotherapy and NanoTherm ${ }^{\circledR}$ in combination with radiotherapy vs. radiotherapy alone in recurrent/progressive glioblastoma. The study is now closed and the final report of the data will be submitted to the official bodies this year (Magforce, 2013, 2018).

\section{MAGNETIC IRON OXIDE NANOPARTICLES FOR MAGNETIC HYPERTHERMIA}

The most commonly used materials for magnetic hyperthermia are nanometre size $(10-100 \mathrm{~nm})$ ferrite nanoparticles, in particular magnetite $\left(\mathrm{Fe}_{3} \mathrm{O}_{4}\right)$ or maghemite $\left(\gamma-\mathrm{Fe}_{2} \mathrm{O}_{3}\right) . \mathrm{Fe}_{3} \mathrm{O}_{4}$ and $\gamma-\mathrm{Fe}_{2} \mathrm{O}_{3}$ are commonly and collectively referred to as MIONs. The magnetic properties of MIONs arise from the presence of ions with different valency in their crystal structure.
For instance, $\mathrm{Fe}_{3} \mathrm{O}_{4}$ consists of two trivalent iron (III) ions and one divalent iron (II) ion. The unpaired ions result in parallel but oppositely aligned magnetic moments that do not cancel out and thus are subject to strong, spontaneous magnetization.

When exposed to an alternating magnetic field, MIONs produce heat via two main mechanisms: (1) hysteresis loss and (2) relaxational losses. Hysteresis losses occur in large MIONs which possess multiple magnetic domains. When such particles are subjected to an alternating magnetic field, the orientation of the magnetic moments will align continuously with the direction of the magnetic field as illustrated in Figure 2. This results in a difference in energy that is released in the form of heat (Kirschning et al., 2012). As MION size decreases, the number of magnetic domains will also decrease until a single magnetic domain remains at a threshold size of approximately $128 \mathrm{~nm}$ (Houlding and Rebrov, 2012). Below this size, MIONs are deemed superparamagnetic and in the presence of an AMF, heat is mainly produced by Néel relaxation and Brownian relaxation. Néel relaxation refers to rapid changes in the particle's magnetic moment when exposed to AMF (Figure 2). The rapid realignment is opposed by the particle's crystalline structure, resulting in heat generation. Brownian relaxation refers to the frictional heat generated from the physical rotation of particles within a supporting medium when the particles attempt to realign themselves with the changing magnetic field (Figure 2; Suto et al., 2009; Suriyanto et al., 2017). A more comprehensive discussion on the mechanism of heating is beyond the scope of this review and covered elsewhere (Ruta et al., 2015).

MIONs have the advantage of long term chemical stability and biocompatibility, and ease of surface modification and functionalisation when compared to other types of magnetic susceptible materials such as certain metals (e.g., iron, nickel or cobalt) or metal alloys (e.g., FePt, FeCo), (Dunn et al., 2014). Furthermore, MIONs can act as a contrast agent for computed tomography $(\mathrm{CT})$ at high concentrations and magnetic resonance imaging (MRI) at lower concentrations, with several iron oxide nanoparticles previously approved by the FDA for these applications (Anselmo and Mitragotri, 2015). This is particularly useful since the concentration of the MIONs within the tumor can be estimated via CT and this can aid the estimation of hyperthermia dosimetry (Johannsen et al., 2007b). MIONs have also been shown to enhance the effects of radiotherapy even in the absence of AMF, potentially by increasing the generation 
TABLE 2 | List of randomized clinical trials on hyperthermia combined with chemotherapy.

\begin{tabular}{|c|c|c|c|c|c|}
\hline Reference & Cancer type & $\begin{array}{l}\text { Number of } \\
\text { patients } \\
\text { randomized }\end{array}$ & Type of treatment & Outcomes & $\begin{array}{l}\text { Toxicity from } \\
\text { hyperthermia }\end{array}$ \\
\hline $\begin{array}{l}\text { Ghussen } \\
\text { et al., } 1984\end{array}$ & $\begin{array}{l}\text { Malignant melanoma } \\
\text { of the extremities }\end{array}$ & 107 & $\begin{array}{l}\text { Control arm: Local excision and regional } \\
\text { lymph node dissection } \\
\text { Experimental arm: Local excision and } \\
\text { regional lymph node dissection + } \\
\text { hyperthermia perfusion (via extracorporal } \\
\text { heating of heparinized whole blood, limb } \\
\text { temperatures were elevated to } 42^{\circ} \mathrm{C} \text {, } \\
60 \text { min) with melphalan (added once limb } \\
\text { temperature reached } \geq 40^{\circ} \mathrm{C} \text { ) }\end{array}$ & $\begin{array}{l}\text { Significant improvement } \\
\text { in disease-free survival } \\
p=0.0001 \\
\text { Significant improvement } \\
\text { in survival. } \\
p=0.0207\end{array}$ & $\begin{array}{l}\text { Higher rates of } \\
\text { reversible } \\
\text { post-operative } \\
\text { complications in the } \\
\text { experimental arm }\end{array}$ \\
\hline $\begin{array}{l}\text { Hafström } \\
\text { et al., } 1991\end{array}$ & $\begin{array}{l}\text { Recurrent malignant } \\
\text { melanoma of the } \\
\text { extremities }\end{array}$ & 69 & $\begin{array}{l}\text { Control arm: Surgery } \\
\text { Experimental arm: Surgery + regional } \\
\text { hyperthermic perfusion (via extracorporeal } \\
\text { heating of blood mixed with low molecular } \\
\text { weight dextran and heparin, temperature of } \\
\text { the inflow perfusate was maintained at } \\
41.5-41.8^{\circ} \mathrm{C} \text {, maintained for } 1 \mathrm{~h} \text {, melphalan } \\
\text { added either beginning or at the end of } \\
\text { hyperthermic perfusion) }\end{array}$ & $\begin{array}{l}\text { Improved tumor-free } \\
\text { survival } \\
p=0.044 \\
\text { Difference in median } \\
\text { survival not statistically } \\
\text { significant }\end{array}$ & $\begin{array}{l}\text { Higher rates of } \\
\text { post-operative } \\
\text { complications in the } \\
\text { experimental arm }\end{array}$ \\
\hline $\begin{array}{l}\text { Hamazoe } \\
\text { et al., } 1994\end{array}$ & $\begin{array}{l}\text { Gastric cancer with } \\
\text { gross serosal } \\
\text { invasion but no gross } \\
\text { peritoneal metastasis }\end{array}$ & 82 & $\begin{array}{l}\text { Control arm: Surgery } \\
\text { Experimental arm: Surgery + continuous } \\
\text { hyperthermic peritoneal perfusion with } \\
\text { mitomycin } \mathrm{C} \text { (after gastrectomy, saline } \\
\text { containing mitomycin C was heated and } \\
\text { infused into the peritoneal cavity via silicon } \\
\text { tubes, inflow termperature was maintained } \\
\text { between } 44-45^{\circ} \mathrm{C}, 50-60 \mathrm{~min} \text { ) }\end{array}$ & $\begin{array}{l}\text { No statistically significant } \\
\text { difference in overall } \\
\text { survival. }\end{array}$ & $\begin{array}{l}\text { Higher rates of } \\
\text { transient abnormal } \\
\text { blood profiles after } \\
\text { surgery in the } \\
\text { experimental arm }\end{array}$ \\
\hline $\begin{array}{l}\text { Sugimachi } \\
\text { et al., } 1994\end{array}$ & $\begin{array}{l}\text { Thoracic esophageal } \\
\text { squamous cell } \\
\text { carcinoma }\end{array}$ & 40 & $\begin{array}{l}\text { Control arm: Chemotherapy }+/- \\
\text { Oesophagectomy } \\
\text { Experimental arm: }+ \text { hyperthermia (via } \\
\text { capacitive system involving an endotract } \\
\text { electrode, } 42.5-44^{\circ} \mathrm{C} \text { for } 30 \text { min, } 6 \text { sessions) } \\
+/- \text { Oesophagectomy }\end{array}$ & $\begin{array}{l}\text { Subjective improvement } \\
\text { of dysphagia: } 40 \% \text { in } \\
\text { control arm vs. } 70 \% \text { for } \\
\text { experimental arm } \\
\text { Radiographic } \\
\text { improvement: } 25 \% \text { in } \\
\text { control arm and 50\% in } \\
\text { experimental arm } \\
\text { Histological response: } \\
18.8 \% \text { in control arm vs. } \\
58.3 \% \text { in experimental } \\
\text { arm } p<0 \text { < } 0.05\end{array}$ & $\begin{array}{l}\text { Similar rates of toxicity } \\
\text { between control and } \\
\text { experimental arm }\end{array}$ \\
\hline $\begin{array}{l}\text { Koops et al., } \\
1998\end{array}$ & $\begin{array}{l}\text { Primary cutaneous } \\
\text { melanoma at high } \\
\text { risk of having regional } \\
\text { micrometastases }\end{array}$ & 832 & $\begin{array}{l}\text { Control: Wide excision } \\
\text { Experimental arm: Wide excision and } \\
\text { isolated limb perfusion with melphalan and } \\
\text { mild hyperthermia (limb was perfused } \\
\text { heated perfusate, maintaining tissue } \\
\text { temperatures of } 39-40^{\circ} \mathrm{C} \text { for } 60 \text { min, } \\
\text { melphalan delivered once subcutaneous } \\
\text { temperature reached } 38^{\circ} \mathrm{C} \text { ) }\end{array}$ & No survival benefit & $\begin{array}{l}\text { Higher rates of } \\
\text { transient } \\
\text { post-operative toxicity } \\
\text { in the experimental arm }\end{array}$ \\
\hline $\begin{array}{l}\text { Verwaal et al., } \\
2008\end{array}$ & $\begin{array}{l}\text { Peritoneal } \\
\text { carcinomatosis of } \\
\text { colorectal cancer }\end{array}$ & 105 & $\begin{array}{l}\text { Control: Chemotherapy (5-fluorouracil, } \\
\text { leucovorin weekly for } 26 \text { weeks or until } \\
\text { progression or unacceptable toxicity. If } \\
\text { treated with } 5 \text {-fluorouracil within } 12 \text { months } \\
\text { before randomization, received irinotecan at } \\
3 \text { weekly intervals for } 6 \text { months, or until } \\
\text { progression or intolerable toxicity) + surgery } \\
\text { (only if symptoms of intestinal obstruction). } \\
\text { Experimental arm: Cytoreductive surgery, } \\
\text { intra-operative hyperthermic intraperitoneal } \\
\text { chemotherapy (initial warming via }>31 \\
\text { isotonic dialysis fluid, at } 1-2 \mathrm{l} / \text { min and an } \\
\text { inflow temperature of } 41-42^{\circ} \mathrm{C} \text { for } 90 \text { min, } \\
\text { Mitomycin C added once abdominal } \\
\text { temperature stable at } 40^{\circ} \mathrm{C} \text { ) }+ \text { adjuvant } \\
\text { systemic chemotherapy. }\end{array}$ & $\begin{array}{l}\text { Median follow-up of } \\
\text { almost } 8 \text { years } \\
\text { Median progression-free } \\
\text { survival: } \\
7.7 \text { months for control } \\
\text { arm and } 12.6 \text { months in } \\
\text { hyperthermia arm } \\
p=0.02 \\
\text { Median disease-specific } \\
\text { survival: } 12.6 \text { months in } \\
\text { control arm and } 22.2 \\
\text { months in hyperthermia } \\
\text { arm } \\
p=0.028\end{array}$ & $\begin{array}{l}\text { Toxicity higher for } \\
\text { experimental arm } \\
\text { including } 3 \text { of } 54 \\
\text { patients in the } \\
\text { experimental arm dying } \\
\text { from abdominal sepsis }\end{array}$ \\
\hline
\end{tabular}


TABLE 2 | Continued

\begin{tabular}{|c|c|c|c|c|c|}
\hline Reference & Cancer type & $\begin{array}{l}\text { Number of } \\
\text { patients } \\
\text { randomized }\end{array}$ & Type of treatment & Outcomes & $\begin{array}{l}\text { Toxicity from } \\
\text { hyperthermia }\end{array}$ \\
\hline $\begin{array}{l}\text { Colombo } \\
\text { et al., } 2011\end{array}$ & $\begin{array}{l}\text { Intermediate to } \\
\text { high-risk non-muscle } \\
\text { invasive bladder } \\
\text { cancer }\end{array}$ & 83 & $\begin{array}{l}\text { Control arm: Transurethral resection and } 2 \\
\text { doses of mitomycin } \mathrm{C} \\
\text { Experimental arm: Transurethral resection } \\
\text { and } 2 \text { doses of mitomycin } \mathrm{C}+\text { hyperthermia } \\
\text { (via a } 915 \mathrm{MHz} \text { intravesical radiative } \\
\text { hyperthermia device, median temperature of } \\
42 \pm 2^{\circ} \mathrm{C} \text { for } \geq 40 \text { min, } 8 \times \text { weekly and } 4 x \\
\text { monthly sessions) }\end{array}$ & $\begin{array}{l}\text { Median follow-up } 91 \\
\text { months } \\
\text { 10-year disease-free } \\
\text { survival: } \\
53 \% \text { with } \\
\text { thermochemotherapy } \\
15 \% \text { with chemotherapy } \\
p<0.001\end{array}$ & $\begin{array}{l}\text { Similar rates of acute } \\
\text { and late toxicity } \\
\text { between control and } \\
\text { experimental arm }\end{array}$ \\
\hline $\begin{array}{l}\text { Arends et al., } \\
2016\end{array}$ & $\begin{array}{l}\text { Intermediate to high } \\
\text { risk } \\
\text { non-muscle-invasive } \\
\text { bladder cancer }\end{array}$ & 190 & $\begin{array}{l}\text { Control Arm: Bacillus Calmette-Guerin } \\
\text { immunotherapy } \\
\text { Experimental arm: } 6 \times \text { weekly mitomycin C } \\
+6 \times 6 \text {-weekly maintenance mitomycin } \mathrm{C} \\
\text { and hyperthermia (via a } 915 \mathrm{MHz} \text { intravesical } \\
\text { radiative hyperthermia device, } 42 \pm 2^{\circ} \mathrm{C} \text {, } \\
60 \text { min, } 6 \text { x weekly sessions followed } 6 \\
\text { further treatments at } 6 \text { week intervals) }\end{array}$ & $\begin{array}{l}24 \text { month recurrence free } \\
\text { survival was } 81.8 \% \text { in } \\
\text { experimental arm and } \\
64.8 \% \text { in the control arm } \\
p=0.02\end{array}$ & $\begin{array}{l}\text { Mitomycin C + } \\
\text { Hyperthermia group } \\
\text { associated with less } \\
\text { urinary frequency, } \\
\text { nocturia, incontinence, } \\
\text { hematuria, fever, fatigue } \\
\text { and arthralgia but more } \\
\text { catheterisation } \\
\text { difficulties, urethral } \\
\text { strictures, bladder } \\
\text { tissue reaction, bladder } \\
\text { spasms, bladder pain, } \\
\text { allergies }\end{array}$ \\
\hline
\end{tabular}

of reactive oxygen species (ROS) through the Fenton reaction (Huang et al., 2010; Klein et al., 2012; Khoei et al., 2014; Bouras et al., 2015). Finally, iron is an essential component of the human body and the average human adult naturally carries approximately 3.5-4 grams of iron. Consequently, unlike other inorganic nanoparticles, MIONs have been systemically delivered safely in large quantities in clinical settings (Hetzel et al., 2014). Furthermore, there is in vitro evidence that intracellular localized heating of ligand-decorated MIONS can lead to lysosomal damage of the target cells and induce cell death even in the absence of bulk heating (Creixell et al., 2011; Domenech et al., 2013).

\section{MODE OF DELIVERY}

MIONs can potentially be delivered to the tumor via intratumoral, intra-peritoneal, intra-arterial, intra-cavitary, and intravenous administration. Oral administration of MIONs is not feasible as most of the nanoparticles will be fecally excreted, owning to their large size (Chamorro et al., 2015). Intra-tumoral administration of MIONs efficiently localizes MIONs in the tumor and can result in effective heating of primary tumors such as prostate cancer. Intra-tumoral administration can result in very high concentrations of MIONs within the tumor and can remain localized in the tumor. When MIONs were directly injected to the prostate in men with localized prostate cancer, MIONs were still clearly visible on CT 6 weeks post injection, thereby allowing repeated magnetic hyperthermia treatments (Johannsen et al., 2005). In a separate post-mortem study of patients with glioblastoma who received MIONs, nanoparticles were restricted to the site of intra-tumoral injection, once again confirming a good retention profile (Van Landeghem et al., 2009). However, intra-tumoral delivery of MIONs is not practical for larger tumors with regional metastases and is more invasive than other techniques (Figure 3). Furthermore, poorly defined tumors like GBM may be better targeted by intravenously delivered MIONs which are less dependent on the operator for effective delivery, although penetrating the blood-brain barrier may be a challenge.

Intra-peritoneal mode of delivery is well suited to cancers that often spread to the peritoneal cavity such as ovarian, pancreatic and gastric cancers. Cancer targeting MIONs have been successfully delivered via the intra-peritoneal route and have demonstrated significant uptake by both primary and metastatic tumors in orthotopic mouse pancreatic cancer models (Gao et al., 2017). When compared to intravenous mode of delivery, the intra-peritoneal route achieved an intra-tumoral level that was 3 -fold higher. The same system was able to carry chemotherapeutic drugs and significantly inhibited pancreatic tumors without systemic toxicity (Gao et al., 2017). Toraya-Brown et al. administered non-targeted MIONs intraperitoneally in an aggressive mouse metastatic ovarian cancer model and demonstrated significant accumulation of MIONs in the tumor (Toraya-Brown et al., 2013). They determined that the non-targeted MIONs were taken up by peritoneal phagocytes and delivered to tumors. When under an AMF, MIONs generated enough heat to induce cell death within tumors. A separate mouse study determined that up to $5 \mathrm{mg} / \mathrm{kg}$ of MIONs can be safely delivered intraperitoneally although at higher levels, signs of oxidative damage were detected within the hepatic and renal tissues (Ma et al., 2012). Furthermore, monocyte/macrophagelike cells with a propensity to migrate into tumors, can be loaded with MIONs externally and injected intraperitoneally, after which the cells will direct MIONs for magnetic hyperthermia (Basel et al., 2012). 
TABLE 3 | List of randomized clinical trials on hyperthermia combined with radiotherapy and chemotherapy.

\begin{tabular}{|c|c|c|c|c|c|}
\hline Reference & Cancer type & $\begin{array}{l}\text { Number of } \\
\text { patients } \\
\text { randomized }\end{array}$ & Type of treatment & Outcomes & $\begin{array}{l}\text { Toxicity from } \\
\text { hyperthermia }\end{array}$ \\
\hline $\begin{array}{l}\text { Kitamura et al., } \\
1995\end{array}$ & $\begin{array}{l}\text { Squamous cell } \\
\text { carcinoma of the thoracic } \\
\text { esophagus undergoing } \\
\text { neoadjuvant therapy }\end{array}$ & 66 & $\begin{array}{l}\text { Control arm: Neoadjuvant } \\
\text { chemoradiotherapy + surgery } \\
\text { Experimental arm: Neoadjuvant } \\
\text { hyperthermochemoradiotherapy } \\
\text { (capacitive system involving an } \\
\text { intraluminal applicator, } 42.5-44^{\circ} \mathrm{C} \\
\text { at tumor surface for } 30 \mathrm{~min}, 6 \\
\text { sessions) }\end{array}$ & $\begin{array}{l}\text { Complete response } \\
25 \% \text { in experimental arm } \\
5.9 \% \text { in control arm } \\
3 \text { year survival } 50.4 \% \\
\text { experimental arm } \\
24.2 \% \text { control arm }\end{array}$ & $\begin{array}{l}\text { Details lacking } \\
\text { No postoperative } \\
\text { mortality in either arm }\end{array}$ \\
\hline $\begin{array}{l}\text { Sneed et al., } \\
1998\end{array}$ & Glioblastoma & 79 & $\begin{array}{l}\text { Control arm: Radiotherapy + oral } \\
\text { hydroxyurea + brachytherapy } \\
\text { boost } \\
\text { Experimental arm: Radiotherapy + } \\
\text { oral hydroxyurea + brachytherapy } \\
\text { boost + hyperthermia (radiative } \\
\text { hyperthermia, } 915 \mathrm{MHz}, \geq 42.5^{\circ} \mathrm{C} \\
\text { for } 30 \text { min, } 15-30 \text { min before and } \\
\text { after brachytherapy) }\end{array}$ & $\begin{array}{l}\text { Median survival: } \\
76 \text { weeks for control arm } \\
85 \text { weeks for hyperthermia } \\
\text { arm } \\
p=0.02\end{array}$ & $\begin{array}{l}\text { There was a trend }(p= \\
0.08 \text { ) toward more } \\
\text { grade } 3 \text { or higher } \\
\text { toxicities for the } \\
\text { experimental arm } \\
\text { Higher incidence of } \\
\text { grade } 1 \text { and grade } 2 \\
\text { neurological changes } \\
\text { and seizures for the } \\
\text { experimental arm }\end{array}$ \\
\hline $\begin{array}{l}\text { Issels et al., } \\
2010\end{array}$ & $\begin{array}{l}\text { Localised high-risk } \\
\text { soft-tissue sarcoma, } \\
\text { extremity and } \\
\text { retroperitoneal }\end{array}$ & 341 & $\begin{array}{l}\text { Control arm: Neoadjuvant and } \\
\text { adjuvant chemotherapy } \\
\text { (etoposide, ifosfamide, } \\
\text { doxorubicine) + local therapy } \\
\text { (surgery +/- radiotherapy) } \\
\text { Experimental arm: Neoadjuvant } \\
\text { and adjuvant chemotherapy } \\
\text { (etoposide, ifosfamide, } \\
\text { doxorubicine) + local therapy } \\
\text { (surgery +/- radiotherapy) + } \\
\text { regional hyperthermia (radiative } \\
\text { hyperthermia, } 42^{\circ} \mathrm{C} \text { for } 60 \text { min on } \\
\text { day } 1 \text { and } 4 \text { of } 3 \text { weekly } \\
\text { chemotherapy cycles, up to } 8 \\
\text { sessions) }\end{array}$ & $\begin{array}{l}\text { Median follow-up } 34 \\
\text { months } \\
\text { Significant improvement in } \\
\text { local progression-free } \\
\text { survival (hazard ratio }= \\
0.58, p=0.003 \text { ) and } \\
\text { disease-free survival (hazard } \\
\text { ratio }=0.7, p=0.011 \text { ) }\end{array}$ & $\begin{array}{l}\text { Increased pain, bolus } \\
\text { pressure, skin burn in } \\
\text { experimental arm }\end{array}$ \\
\hline
\end{tabular}

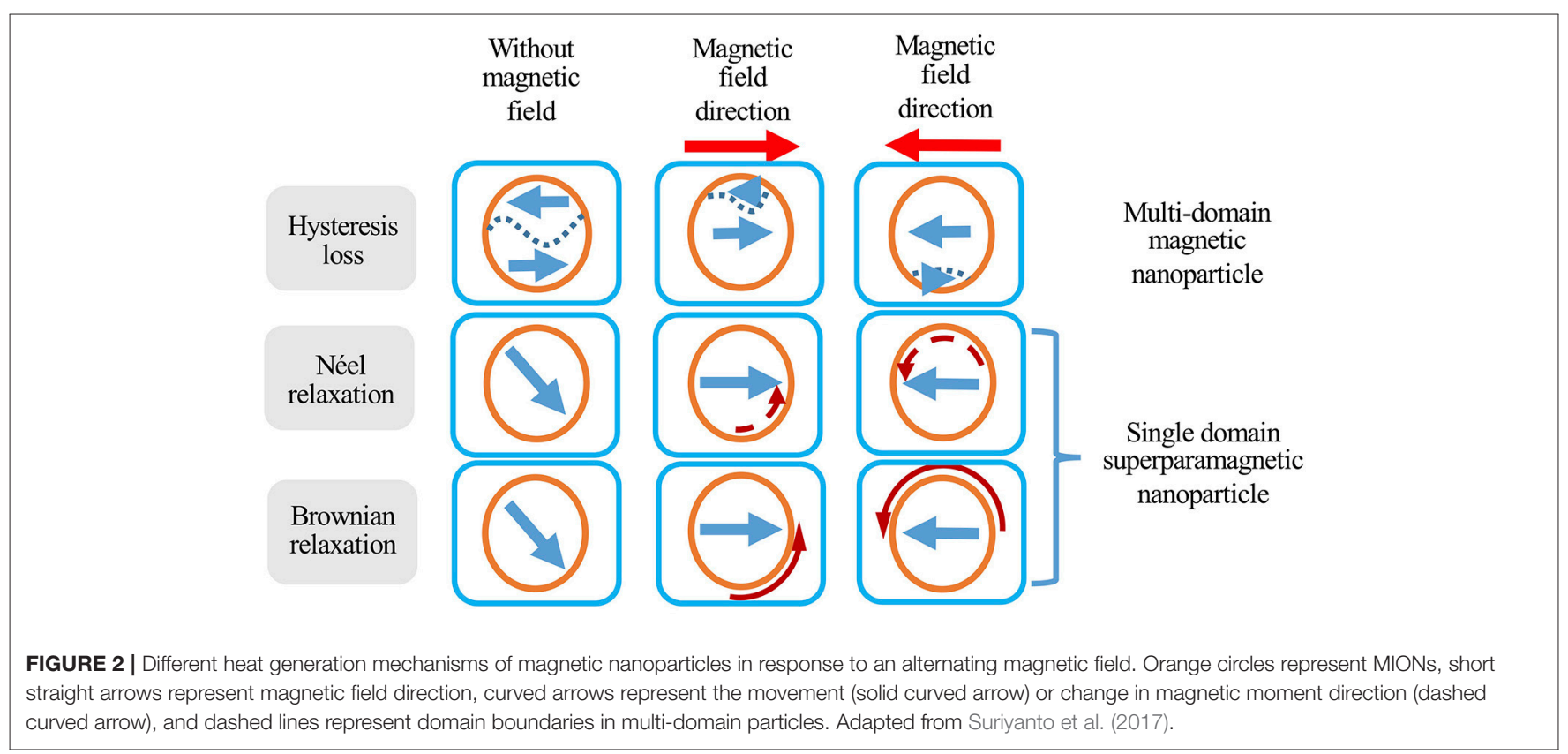


A

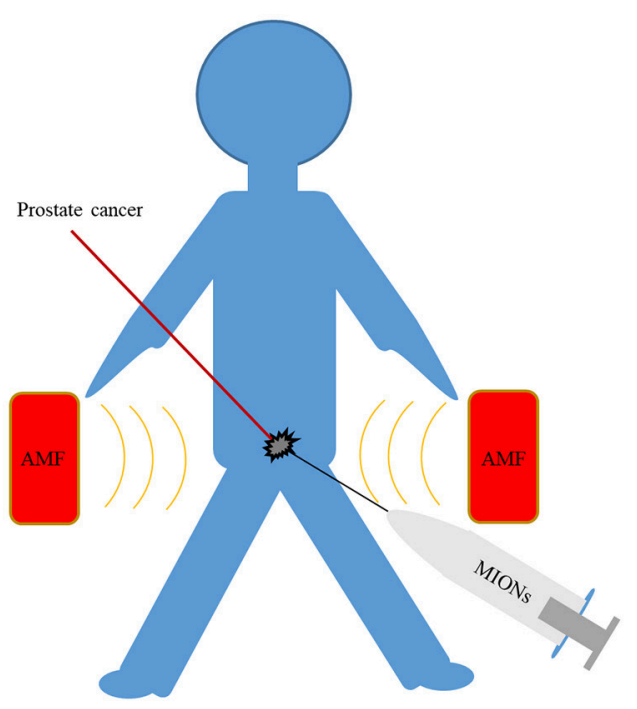

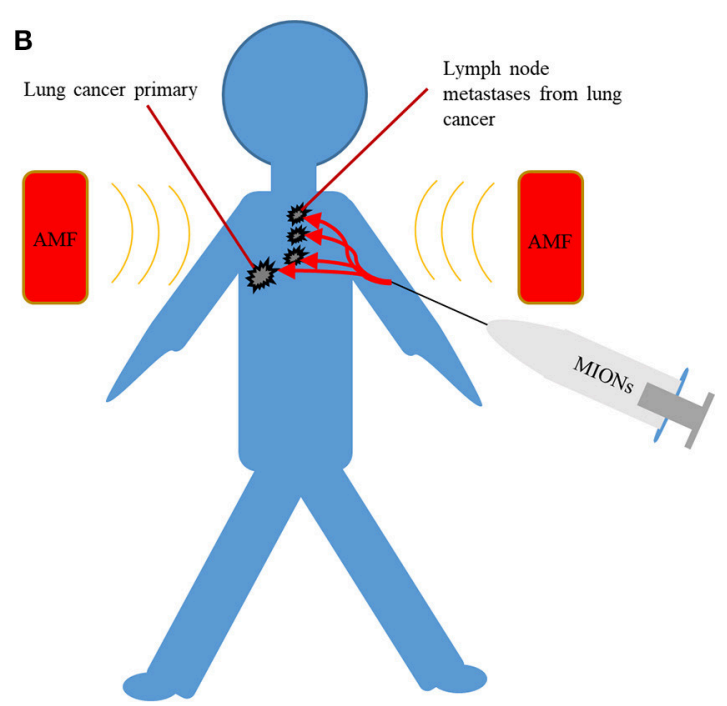

FIGURE 3 | (A) Intra-tumoral delivery can achieve high concentrations of MIONs but are only suited to localized disease such as prostate cancer. (B) Intravenous delivery can potentially target poorly localized malignancies, often with lymph node metastases, such as lung cancer. AMF, alternating magnetic field; MIONs, magnetic iron-oxide nanoparticles.

For bladder cancers, magnetic hyperthermia can be achieved by the direct injection of MIONs into the bladder cavity via a urinary catheter. The thick lining of the bladder will restrict the absorption of MIONs and once the treatment is completed, MIONs can be removed through the catheter, thereby minimizing systemic toxicity. The feasibility of this approach was demonstrated by Oliveira et al. in rat bladders, where temperatures of $42^{\circ} \mathrm{C}$ were maintained in the bladder with minimal heating of surrounding tissues (Oliveira et al., 2013).

Intra-arterial administration of chemotherapeutic drugs has been successfully applied to liver cancers in the clinic. MIONs may be well suited to this task as they tend to accumulate in the liver via the reticuloendothelial system. With this in mind, the arterial delivery of iron oxide nanoparticles has been explored in preclinical models by several investigators (Lee et al., 2013, 2017; Kim et al., 2016). In rabbits, when MIONs were delivered with iodized oil and doxorubicin, there was an increased intra-tumoral accumulation of drugs and consequently, reduced numbers of viable tumor cells (Lee et al., 2013). For lung cancer, there have been early investigations into the potential formulation of aerosolized MIONs and their delivery via a combination of a nebulizer and a magnet (Dames et al., 2007; Tewes et al., 2014; Graczyk et al., 2015). However, it would be quite challenging to deliver sufficient quantities of MIONs for the application of magnetic hyperthermia using this approach.

Although the modes of administration mentioned so far are well suited to particular scenarios, intravenous administration is the most versatile method of delivery for the widest range of cancers. Not surprisingly, intravenous delivery is one of the most common routes of administration of chemotherapeutic drugs and in the past, FDA-approved MION MRI contrast agents have been delivered intravenously. (Figure 3). When MIONs are delivered in this manner, the accumulation of nanoparticles within the tumor depends in part on the enhanced permeability and retention (EPR) effect (Iyer et al., 2006). The EPR effect refers to the tendency of nanoparticles to preferentially accumulate within tumors due to their leaky vasculatures and poor lymphatic drainage. Once nanoparticles have reached the tumor, targeting ligands, such as small molecules, peptides or antibodies, bound to MIONs may lead to increased association and uptake of nanoparticles by malignant cells (DeNardo et al., 2007; Balivada et al., 2010). Their preferential accumulation within the malignant cells can lead to targeted heating of tumors and sparing of adjacent normal tissue under AMF (DeNardo et al., 2007; Balivada et al., 2010). Such approaches may potentially result in more homogeneous delivery of MIONs to the tumor and would be far less operator dependent when compared to other forms of targeting. In addition, the avoidance of the surgical morbidity associated with intra-tumoral injection of MIONs in the tumor may be attractive.

So far, preclinial in vivo studies (Table 4) have been performed in order to demonstrate the concept of biologically targeted magnetic hyperthermia (Table 4). Huang et al. intravenously injected extremely large quantities $(1,700 \mathrm{mg} \mathrm{Fe} / \mathrm{kg})$ of untargeted MIONs into mice and achieved a subcutaneous tumor concentration of $1.9 \mathrm{mg} \mathrm{Fe} / \mathrm{kg}$ of tumor. Despite the lack of targeting moiety, they were able to achieve a tumor to surrounding non-tumor concentration ratio of more than 16:1 via the enhanced permeability and retention effect alone. Application of AMF achieved significant tumor control when compared to either nanoparticles or AMF alone. In the same study, mice injected with even higher doses of nanoparticles (3,400 mg Fe/kg) survived more than 12 months without showing any clinical signs of toxicity (Huang and Hainfeld, 2013). Another in vivo study on intravenous administration of porphyrin coated MIONs demonstrated improved melanoma 
tumor control under AMF (Balivada et al., 2010). A third mouse study assessing the effectiveness of MIONs conjugated to ChL6, an antibody that targets tumor-associated antigen L6, demonstrated significant tumor accumulation and breast cancer tumor growth delays (DeNardo et al., 2007).

Despite the promising findings outlined above, preclinical studies often apply field strengths, frequencies or quantities of MIONs that are beyond what is clinically feasible and thus, further research is warranted in the areas of design, delivery, and the heating of nanoparticles, to achieve clinical translation in the future. In the following sections, areas requiring further research will be highlighted.

\section{FACTORS INFLUENCING THE EFFICACY OF BIOLOGICALLY TARGETED MAGNETIC HYPERTHERMIA}

\section{Field Strength and Frequency}

Achieving and maintaining hyperthermia in the tumor is no easy task. Due to natural thermoregulatory processes, significant power must be delivered to elevate the temperature of a particular region of the body. The heating of MIONs is dependent on a variety of factors including the concentration of MIONs, frequency and the field strength. Currently, the only clinically available AMF system in the world, NanoActivator ${ }^{\circledR}$ (MagForce AG, Germany), can operate at a frequency of $100 \mathrm{kHz}$ and is able to apply fields up to $18 \mathrm{kA} / \mathrm{m}$ (Jordan et al., 2001). Although higher frequencies are technically feasible, $100 \mathrm{kHz}$ was chosen to minimize eddy currents and maximize the temperature differential between normal tissues and tumors containing magnetic nanoparticles (Jordan et al., 1993). Eddy currents are electrical currents that are induced within the conductor, in this case the human body, due to the changing magnetic field, as described by Faraday's law of induction. Excessive non-specific heating of normal tissues by eddy currents is the primary determinant of the maximum tolerable field strength and frequency.

At present, there is limited clinical data on the maximum tolerable field strength and frequency. In 1984, Atkinson et al. designed a single-turn induction coil for interstitial magnetic seed therapy and conducted experiments on thoraces of numerous volunteers. They found that field intensities up to $35.8 \mathrm{~A} / \mathrm{m}$ at a frequency of $13.56 \mathrm{MHz}$ can be tolerated for extended periods of time. Based on this study, the assumption was made that the product of field strength and frequency should not exceed $4.85 \times 10^{8} \mathrm{~A} / \mathrm{m} \cdot \mathrm{s}$ (Atkinson et al., 1984). However, this is not an absolute limit and in certain scenarios, this limit may be exceeded (Dutz and Hergt, 2013; Obaidat et al., 2015). In phase 1 and 2 trials of the MagForce system, using lower frequencies of $100 \mathrm{kHz}$, patients with glioblastoma were able to tolerate up to $13.5 \mathrm{kA} / \mathrm{m}\left(1.35 \times 10^{9} \mathrm{~A} / \mathrm{m} \cdot \mathrm{s}\right.$ or a median value of $8.5 \times$ $10^{8} \mathrm{~A} / \mathrm{m} \cdot \mathrm{s}$ ) whilst patients with prostate cancer were only able to tolerate up to $5 \mathrm{kA} / \mathrm{m}\left(5 \times 10^{8} \mathrm{~A} / \mathrm{m} \cdot \mathrm{s}\right)$ due to discomfort in the groin and/or perineal regions (Johannsen et al., 2007a; Maier-Hauff et al., 2007; Nieskoski and Trembly, 2014). This may have been due to boundary effects between tissues of different dielectric constants and conductivity, as well as narrowing of current path in the skin folds such as the groin, resulting in hot spots (Johannsen et al., 2007a). The higher tolerable field strength in patients with glioblastoma is likely to be due to the smaller radius of the head compared to the pelvis or thorax in other studies. Considering that higher field strengths and frequencies will translate to improved heating of tumors, further research is required into improving the tolerable limits of magnetic field strengths and frequencies via improved surface cooling of hotspots that develop in the body, such as the groin (Johannsen et al., 2007b). Furthermore, with shorter duration of treatment, it is possible that higher magnetic field strength or frequency may be achievable. Another possible limitation to the maximum field strength that can be applied clinically relates to the technical challenges of designing and manufacturing a much larger system than the smaller systems utilized in the preclinical studies (Table 4; Jordan et al., 2001). It is advisable that future preclinical studies on biologically targeted magnetic hyperthermia focus on the application of clinically relevant magnetic field strength and frequency of $18 \mathrm{kA} / \mathrm{m}$ and $100 \mathrm{kHz}$ currently available on the MagForce system.

Assuming that MIONs have been delivered to the target, the temperature can be adjusted by the alteration of magnetic field strength or frequency. For example, the hyperthermia system from Magforce controls the temperature by adjusting the magnetic field strength. As the effect of hyperthermia is heavily influenced by the temperature reached and for how long this is maintained, it is extremely important to accurately monitor the temperature during therapy and this has been previously achieved with an invasive catheter or specialized software based on imaging (Mahmoudi et al., 2018). Future studies must ensure that hyperthermia is delivered sufficiently by close monitoring of the tumor temperature.

\section{DOSING AND TOXICITY OF MAGNETIC IRON OXIDE NANOPARTICLES}

The rate of AMF-induced heating is highly dependent on the concentration of MIONs within the tumor. In clinical trials, up to $31.36 \mathrm{mg}$ of $\mathrm{Fe} / \mathrm{cm}^{3}$ of tumor, in the form of MIONs, have been administered intra-tumorally in patients with glioblastoma (Maier-Hauff et al., 2011). Feraheme ${ }^{\circledR}$ (AMAG Pharmaceuticals, USA), an FDA approved iron oxide nanoparticle indicated for iron replacement, has been safely delivered intravenously in larger quantity than probably any other FDA approved inorganic nanoparticle so far and the recommended dose is $510 \mathrm{mg}$ of $\mathrm{Fe}$ in the form of Feraheme ${ }^{\circledR}$, followed by a second injection 3 to 8 days later. In the past, several patients have received two additional injections to a total dose of $2.02 \mathrm{~g}$ of $\mathrm{Fe}$ in the form of Feraheme ${ }^{\circledR}$ within a short period (Lu et al., 2010). In a hypothetical scenario, if $2.02 \mathrm{~g}$ of $\mathrm{Fe}$ in the form of MIONs, are intravenously administered to a patient with a $35 \mathrm{ml}$ prostate tumor, and assuming that $1 \%$ of the dose would reach the tumor, this would result in only about $0.6 \mathrm{mg}$ of $\mathrm{Fe} / \mathrm{cm}^{3}$ of tumor, far lower than what has been achieved with intra-tumoral administration. In addition, Feraheme contains approximately $3 \mathrm{~nm}$ iron oxide cores that are smaller than the MIONs that are typically associated with effective heating (Bullivant et al., 
TABLE 4 | In vivo studies of biologically targeted magnetic hyperthermia.

\begin{tabular}{|c|c|c|c|c|c|c|c|}
\hline Reference & $\begin{array}{c}\text { Field } \\
\text { strength } \\
(\mathrm{kA} / \mathrm{m})\end{array}$ & $\begin{array}{c}\text { Frequency } \\
\text { (kHz) }\end{array}$ & $\begin{array}{l}\text { Field strength } \\
\text { x frequency } \\
\text { (A/mes) }\end{array}$ & $\begin{array}{l}\text { Quantity of } \\
\text { Fe delivered }\end{array}$ & Target & $\begin{array}{l}\text { Targeting } \\
\text { Mechanism }\end{array}$ & Summary of Results \\
\hline $\begin{array}{l}\text { Huang (Huang and } \\
\text { Hainfeld, 2013) }\end{array}$ & 38 kA/m & $980 \mathrm{kHz}$ & $3.724 \times 10^{10}$ & 1700 mg/kg & $\begin{array}{l}\text { Squamous Cell } \\
\text { Carcinoma }\end{array}$ & EPR & $\begin{array}{l}\text { Durable ablation of tumors } \\
\text { in } 84 \% \text { of hyperthermia } \\
\text { group compared to } 0 \% \text { for } \\
\text { controls }\end{array}$ \\
\hline $\begin{array}{l}\text { Balivada (Balivada } \\
\text { et al., 2010) }\end{array}$ & $5 \mathrm{kA} / \mathrm{m}$ & $366 \mathrm{kHz}$ & $1.830 \times 10^{9}$ & $13.30 \mathrm{mg} / \mathrm{kg}^{\star}$ & Melanoma & EPR + Porphyrins & $\begin{array}{l}\text { Tumor volume was smaller } \\
\text { in the hyperthermia group } \\
(p<0.1)\end{array}$ \\
\hline $\begin{array}{l}\text { DeNardo } \\
\text { (DeNardo et al., } \\
\text { 2007) }\end{array}$ & $56-113$ kA/m & $153 \mathrm{kHz}$ & $1.729 \times 10^{10}$ & $150 \mathrm{mg} / \mathrm{kg}^{\star}$ & Breast Cancer & $\begin{array}{l}\text { EPR }+ \text { Antibody } \\
\text { targeting integral } \\
\text { membrane } \\
\text { glycoprotein }\end{array}$ & $\begin{array}{l}\text { Tumor } \\
\text { doubling/tripling/quadrupling } \\
\text { times were increased } \\
\text { significantly }(p<0.05) \\
\text { except for the group that } \\
\text { received the lowest energy }\end{array}$ \\
\hline
\end{tabular}

${ }^{*}$ Assuming $20 \mathrm{~g}$ average weight of mice.

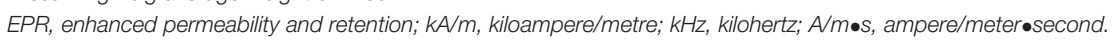

2013). For example, the nanoparticles used by MagForce contain a $12 \mathrm{~nm}$ iron oxide core surrounded by aminosilanes and larger crystal cores are likely to be associated with different toxicity profiles. In mice, Huang et al. was able to deliver much higher concentrations of MIONs $(5.1 \mathrm{~g} \mathrm{Fe} / \mathrm{kg})$ and determined an $\mathrm{MTD}_{50}$ value of $4.7 \mathrm{~g} \mathrm{Fe} / \mathrm{kg}$, more than 100 times that delivered per kg in the Feraheme study (Huang and Hainfeld, 2013).

As the interaction of MIONs with their biological environment, and therefore their toxicity, varies with morphology, size, and surface modifications such as the addition of biocompatible coatings and targeting moieties, as well as the route of administration, each formulation needs to be tested thoroughly in vitro and in vivo. MIONs can mediate toxicity through several mechanisms that all have to be taken into account when evaluating their safety. Most intracellular toxicity is caused by generation of reactive oxygen species whereas in vivo disturbances of blood clotting, iron homeostasis and macrophage function, as well as organ toxicities, are additional considerations (Ilinskaya and Dobrovolskaia, 2013; Wu et al., 2014; Wei et al., 2016; Shah and Dobrovolskaia, 2018). A more detailed discussion of MION toxicity can be found in specialized review articles (Reddy et al., 2012; Liu et al., 2013; Arami et al., 2015).

To achieve sufficient heating via intravenous delivery of MIONs, further research is necessary to assess the tolerability of larger quantities of MIONs with bigger cores which are more suited to magnetic hyperthermia, and this will have to be finely balanced with size requirements for efficient intra-tumoral accumulation of nanoparticles.

\section{HEATING EFFICIENCY OF MAGNETIC IRON OXIDE NANOPARTICLES}

In order to minimize the quantity of iron oxide nanoparticles necessary for adequate magnetic hyperthermia, the development of nanoparticles with higher heating efficiency is desirable. The most common parameter for quantifying the heat generated via magnetic induction of MIONs is the Specific Absorption Rate (SAR). The experimental measurement of SAR is relatively simple. It typically involves suspending a known amount of MIONs in a liquid of known heat capacity. The test sample is exposed to an AMF of a specific strength and frequency, and the change in temperature is measured continuously over a period of time. The temperature measurement is carried out with fiber optic temperature probes to avoid electromagnetic interference with the measurement. The SAR is then calculated from the following equation (Kallumadil et al., 2009; Huang et al., 2012):

$$
S A R=\left.\frac{C}{m_{n p}}\left(\frac{d T}{d t}\right)\right|_{t=0}
$$

where $C$ is heat capacity of the fluid per unit mass of fluid, $m_{n p}$ is the mass of magnetic phase suspended in the fluid and $d T / d t$ refers to the initial slope of temperature rise $T$, as a function of time, $t$.

It is important to note that SAR is a system-dependent parameter, that is, its value depends on the strength $(\mathrm{H})$ and frequency (f) of the applied magnetic field. Therefore, direct comparison between measurements that are made using different field strength and frequency is not possible. A better parameter for this purpose is the Intrinsic Loss Power (ILP) which is mathematically described by the equation below (Kallumadil et al., 2009):

$$
I L P=\frac{S A R}{H^{2} f}=\left.\frac{C}{H^{2} f m_{n p}}\left(\frac{d T}{d t}\right)\right|_{t=0}
$$

The ILP parameter is introduced under several key assumptions: (1) Test samples are single domain nanoparticles that heat up mainly via rotational relaxation; (2) Magnetic induction systems are of low frequencies at approximately $10^{5}-10^{6} \mathrm{~Hz}$; (3) Applied field strength is under the saturation field of the MIONs; (4) For the case of polydisperse MIONs in solution, the crystallite 
polydispersity index (PDI) has to be greater than 0.1 (Rosensweig, 2002; Kallumadil et al., 2009). If these assumptions are not satisfied, the derived ILP values may not be valid. It is important to note that the published ILPs are only a guide, and the absolute values may not always be reliable due to the variability in the methods used to measure them and given the heating rates are very sensitive to factors such as polydispersity (GonzalesWeimuller et al., 2009; Wildeboer et al., 2014). Different types of MIONs have highly variable heating properties. Kallumadil et al. found significant variations in the ILP between various commercially available MIONs, ranging from 0.15 to 3.12 $\mathrm{nHm}^{2} / \mathrm{kg}$. Heating rates can be influenced by several factors such as the ferrous iron content, size, hydrodynamic diameter, shape, number of cores, method of synthesis, and introduction of other metals such as $\mathrm{Mn}$ and $\mathrm{Zn}$ (Kallumadil et al., 2009; Blanco-Andujar et al., 2015; Hauser et al., 2015; Phong et al., 2017).

Due to the large number of variables, it is difficult to determine precisely how individual factors can impact the heating performance. In addition, the viscosity of the solvent and concentration of MIONs can further dictate the heating properties (Salas et al., 2014). Despite this, there are studies that do provide general insights to the relationship between the various characteristics and the heating properties. Several investigators have shown that in general, larger MIONs are more efficient at generating heat than smaller MIONs. (GonzalesWeimuller et al., 2009; Lartigue et al., 2011; de La Presa et al., 2012; Jeun et al., 2012). For example, Lartigue et al. produced MIONs ranging from 4 to $35 \mathrm{~nm}$ and coated them with rhamnose, a type of sugar. When heated under $168 \mathrm{kHz}$ and $21 \mathrm{kA} / \mathrm{m}$, the SAR was $0 \mathrm{~W} / \mathrm{g}$ of Fe for $4 \mathrm{~nm}$ MIONs, $32 \mathrm{~W} / \mathrm{g}$ of Fe for $10 \mathrm{~nm}$ MIONs, $61 \mathrm{~W} / \mathrm{g}$ of Fe for $16 \mathrm{~nm} \mathrm{MIONs,} \mathrm{and} 76 \mathrm{~W} / \mathrm{g}$ of Fe for $35 \mathrm{~nm}$ MIONs (Lartigue et al., 2011).

The shape of the nanoparticle can have a significant influence on the heating performance. Song et al. produced and compared the heating performance of quasi-cubical and spherical $\mathrm{Fe}_{3} \mathrm{O}_{4}$ nanoparticles under $100 \mathrm{kHz}$ and $30 \mathrm{kA} / \mathrm{m}$. Under equal concentration of $\mathrm{Fe}$, the SAR for quasi-cubical nanoparticles were far superior (Song et al., 2012). Another study by Nemati et al. compared deformed cube (octopods) shaped MIONs with spherical nanoparticles of similar volume and demonstrated superior heating performance of the octopods (Nemati et al., 2016). Liu et al. produced ring shaped MIONs (nanorings) and compared the heating performance with a commercial MION called Resovist across a range of magnetic field strengths. Although the difference cannot be entirely attributed to the shape alone due to the differences in size, nanorings demonstrated superior heating performance, especially under the higher ranges of magnetic field strength (Liu et al., 2015). Consequently, magnetic hyperthermia via nanorings resulted in superior tumor control in vivo (Liu et al., 2015). Despite the superior heating rates of some of the oddly shaped MIONS, it is important to be aware that the shape can also influence the rate of uptake and toxicity (Hinde et al., 2017). These factors must be considered when designing nanoparticles for clinical applications.

The surface coating can have a significant impact on the heating performance of MIONs. Complete coating of MIONs with a low heat conductor such as $\mathrm{SiO}_{2}$ shell can prevent the outflow of heat and reduce the heating efficiency (GonzalezFernandez et al., 2009; Rivas et al., 2012). Furthermore, the thickness of the coating can also impact the heating efficiency. Liu et al. coated MIONs with polyethylene glycol (PEG) polymer of various length ranging from 2,000 to 20,000 Da and found that MIONs coated with shorter polymers generally heat better, possibly due to increased Brownian loss, improved thermal conductivity and dispersibility (Liu et al., 2012). One exception to this was the $31 \mathrm{~nm}$ MION which heated better when coated with longer PEG polymers. This was ascribed to potential agglomeration of the $31 \mathrm{~nm}$ MIONs with the shorter PEG, highlighting a delicate balance between stability and heating performance. The coating can also influence the pharmacokinetics of MIONs in the body which is an important consideration when developing MIONs for hyperthermia (Arami et al., 2015). Doping MIONs with $\mathrm{Mg}$ or $\mathrm{Zn}$ is another strategy that has resulted in nanoparticles with superior heating profiles, resulting in better tumor control in vivo (Jang et al., 2009).

Interestingly, one of the highest ILPs $\left(23.41 \mathrm{nHm}^{2} / \mathrm{kg}\right)$ to have been reported in the past was on bacterially derived MIONs, which have a mean core diameter of approximately $30 \mathrm{~nm}$ (Hergt et al., 2005). Bacterial magnetosome-like cubic nanoparticles were later produced by Martinez-Boubeta et al. and demonstrated superior heating efficiency compared to spheroidal MIONs of similar size (Martinez-Boubeta et al., 2013). Le Fevre et al. have evaluated the effectiveness of magnetic hyperthermia via intra-tumorally delivered magnetosomes and achieved superior tumor control compared to chemically synthesized MIONs (Le Fèvre et al., 2017). Recently, Sangnier et al. demonstrated that magnetosomes can be tagged with tumor targeting peptide, arginine-glycine-aspartic acid (RGD), then administered intravenously in mice models for targeted delivery to tumors (Plan Sangnier et al., 2018). They applied photothermal therapy rather than magnetic hyperthermia as it was thought to be more effective. However, such approaches are likely to be limited for deep seated tumors in humans and thus, further work is required to evaluate its application for magnetic hyperthermia. Many other types of nanoparticles have been produced in the past for magnetic hyperthermia and more details can be found in other specialized review articles (Blanco-Andujar et al., 2017; Hedayatnasab et al., 2017). Higher heating efficiency would be highly desirable as it would reduce the quantity of nanoparticles, field strength and frequency required to induce significant heating.

\section{TARGETING OF MIONS}

Intravenously administered nanoparticles preferentially accumulate within tumors owing to their leaky vasculature and poor drainage. This EPR effect is well documented and was recently demonstrated in human tumors (Clark et al., 2016). In addition, structural and surface modification of MIONs can further increase tumor accumulation and up to $\sim 15.5 \% \mathrm{ID} / \mathrm{g}$ have been reported in the past (Xu et al., 2016). 
Targeting of cancer cells with antibodies or other ligands can further improve the accumulation of nanoparticles within the tumor. MIONs conjugated to antibodies have been previously delivered to several tumor specific antigens including L6, HER-2 and PSMA for medical imaging and magnetic hyperthermia (DeNardo et al., 2007; Zhang et al., 2011; Tse et al., 2015). As mentioned earlier, one of the best examples is a study by DeNardo et al. in which MIONs conjugated to ChL6, an antibody that targets tumor-associated antigen L6, demonstrated significant tumor accumulation and breast cancer tumor growth delays under an AMF (DeNardo et al., 2007). Despite the potential for enhanced delivery, targeting can be associated with significant challenges in terms of the chemistry of conjugation and stability of ligand or antibody bound to nanoparticles. For example, MLN2704, a prostate specific antigen directed immunoconjugate for delivering chemotherapeutics to prostate cancer was associated with significant toxicity and limited activity due to deconjugation of the targeting antibody once in circulation (Milowsky et al., 2016). In a clinical trial of CALAA-01, a ligand bound nanoparticle siRNA delivery system, $21 \%$ of patients discontinued the study due to an adverse event and it was proposed that ligand instability was responsible for the undesirable toxicity (Zuckerman and Davis, 2015). Some of these limitations can be overcome by the application of bispecific antibodies that can spontaneously bind to both the poly ethylene glycol (PEG) coated nanoparticles and cancer specific antigens such as prostate specific membrane antigen (PSMA) or epidermal growth factor receptor (EGFR). Bispecific antibodies are composed of 2 separate single-chain fragment $(\mathrm{scFv})$ and are smaller than whole antibodies. It can be stored in the freezer separate to the nanoparticles, thereby overcoming the stability issue. When administered with any PEGylated nanoparticles prior to or at the time of delivery, bispecific antibodies will spontaneously associate itself with PEGylated nanoparticles. Within the tumor, bispecific antibodies will bind to cancer specific antigens and keep the nanoparticle in close proximity to the target cancer cells, thereby, enhancing tumor accumulation (Howard et al., 2016).

To overcome the limitations of antibodies, MIONs can alternatively be conjugated to cancer specific peptides, glycosaminoglycans or aptamers. In order to target ovarian cancer, Taratula et al. synthesized MIONs conjugated to an ovarian cancer targeting Luteinizing Hormone-Release Hormone (LHRH) peptide. In vitro, LHRH peptide coating improved the ability of MIONs to associate with ovarian cancer cells and resulted in a significant reduction in cell viability under an alternating magnetic field (Taratula et al., 2013). For reduced immunogenicity, MIONs can be coated with hyaluronic acid, a biocompatible material that is naturally found in our body. Hyaluronic acid can target cancer cells via CD44 receptor, a commonly found cell surface marker in epithelial tumors and its potential role in magnetic hyperthermia has been demonstrated in vitro (Thomas et al., 2015). Nair et al. produced glioma targeting aptamers, composed of oligonucleotides, for conjugation with dextran coated iron oxide nanoparticles. Using the targeted MIONs, they were able to induce preferential damage to glioma cells via mechanical oscillation induced by a rotating magnetic field (Nair et al., 2010). It is possible that such nanoparticles may be applied for magnetic hyperthermia in the future.

For further enhancement of hyperthermia, MIONs can be directed toward intracellular organelles of cancer cells via conjugation of organelle targeting peptides. Peng et al. administered transferrin and nuclear targeting TAT peptide conjugated MIONs to mice and applied photothermal hyperthermia (Peng et al., 2017). When compared to transferrin conjugated MIONs, nuclear targeting MIONs demonstrated significant improvement in tumor control (Peng et al., 2017). Additional studies are required to confirm that such intracellular targeting strategies may be applicable for magnetic hyperthermia. Despite these exciting approaches to targeting, there is multitude of factors that can influence its effectiveness and a detailed evaluation can be found in specialized reviews (Rosenblum et al., 2018).

Another novel approach to improved tumor targeting is to suppress the reticuloendothelial system with drugs prior to the delivery of MIONs. For example, Abdollah et al. demonstrated that the suppression of Kupffer cells in the liver with dextran sulfate can significantly increase the circulating half-life of non-targeted MIONs by inhibiting the liver uptake (Abdollah et al., 2014). It is uncertain whether dextran sulfate suppression can also be applied in combination with ligand- or antibodyconjugated MIONs to prevent liver uptake and further research is warranted in this area.

Overall, several strategies are being evaluated in order to effectively target nanoparticles to the tumor whilst sparing normal tissue. Improved targeting will ultimately be the key to delivering sufficient quantities of MIONs for selective heating of tumors.

\section{MAGNETICALLY TARGETED MIONS}

Due to their magnetic properties, MIONs can be directed toward the tumor via a magnetic field. This can be applied in combination with targeted MIONs for effective magnetic hyperthermia. There are several notable examples of this approach. For gene therapy, MIONs have been used to direct intravenously administered silencing RNAs toward gastric tumors in mouse models under a magnetic field (Namiki et al., 2009). In a separate study, Garcia-Jimeno et al. were able to direct magnetoliposomes, with the aid of a magnetic field, toward the target and away from the liver and the spleen of mice (GarcíaJimeno et al., 2012).

For maximum uptake and retention in the tumor, it is important for MIONs or other nanoparticles to extravasate and reach the cancer cells. This can be achieved by disrupting the endothelial barrier with an external magnetic field. Qui et al. injected MIONs into mouse tail vein and used an external magnetic field to direct the particles into the lateral tail vein. Histological examination revealed that MIONs accumulated in the endothelial tissue. When a fluorophore was injected systemically, fluorescence signal was higher in the tail of the mice 
subjected to the magnetic field and MIONs, due to a disruption of endothelial lining (Qiu et al., 2017). Combining these approaches may potentially improve the therapeutic efficacy of magnetic hyperthermia in the future.

\section{OTHER METHODS TO IMPROVE THE IMPACT OF TARGETED MAGNETIC HEATING}

Other novel methods of improving the effectiveness of magnetic hyperthermia have been explored. Espinosa et al. applied near-infrared laser irradiation $(808 \mathrm{~nm})$ during magnetic hyperthermia in vivo and demonstrated 2-5 fold improvements in heating when compared to magnetic hyperthermia alone although such approaches would be limited to surface tumors owing to the poor tissue penetration of laser irradiation (Espinosa et al., 2016).

In the past, there have been attempts to biologically enhance the effectiveness of magnetic hyperthermia with hyperthermia enhancing drugs such as the heat shock protein (HSP) 90 inhibitor Geldanomycin. When cells are heated, HSP 90 plays a key role in stabilizing proteins, thus, limiting the downstream effects of protein denaturation. Therefore, the inhibition of HSP 90 can lead to improved effectiveness of hyperthermia and reduce thermotolerance. For example, Ito et al. delivered Geldanomycin, and applied magnetic hyperthermia in a mouse melanoma model, which resulted in significant improvement in tumor control when compared to magnetic hyperthermia alone (Ito et al., 2009). This approach is particularly promising as HSP 90 inhibitors can independently enhance the effectiveness of radiotherapy, even in the absence of hyperthermia (Schilling et al., 2015).

There are many other hyperthermia enhancers that have been reported in the past but the majority of these agents have not been evaluated in combination with magnetic hyperthermia (Marchal et al., 1986). Protease inhibitors are another class of potent hyperthermia enhancers that have been evaluated in vitro. It is thought that the enhancement is achieved by inhibiting the clearance of denatured proteins within the cells (Zhu et al., 1995).

Another novel strategy is to combine magnetic hyperthermia with thermally sensitive liposomes. This can be achieved by creating a liposome with magnetic iron oxide cores embedded within. When an AMF is applied, the magnetic nanoparticles will trigger the release of the lipososomal contents. As AMF can be applied to a specific region of the body, this could result in targeted drug release and improved therapeutic

\section{REFERENCES}

Abdollah, M. R., Kalber, T., Tolner, B., Southern, P., Bear, J. C., Robson, M., et al. (2014). Prolonging the circulatory retention of SPIONs using dextran sulfate: in vivo tracking achieved by functionalisation with near-infrared dyes. Faraday Discuss 175, 41-58. doi: 10.1039/C4FD00114A

Anselmo, A. C., and Mitragotri, S. (2015). A review of clinical translation of inorganic nanoparticles. AAPS J. 17, 1041-1054. doi: 10.1208/s12248-015-9780-2 effectiveness. For example, Yang et al. produced a CD90 targeted magnetoliposome encapsulating 17-AAG, a HSP 90 inhibitor. The magnetoliposome was able to simultaneously heat liver cancer stem-like cells and trigger the release of 17-AAG, thereby improving the effectiveness of magnetic hyperthermia (Yang et al., 2015).

\section{CONCLUSION}

Hyperthermia can lead to cell death via modulation of various cellular processes and is an effective treatment that can enhance the outcomes of radiotherapy and chemotherapy. One of the disadvantages is the lack of specificity toward malignant cells compared to healthy tissue. Systemic administration of targeted MIONs has the potential to improve the specificity of hyperthermia and improve its efficacy. However, several limitations must be resolved before this technology can progress to clinic. Future preclinical studies should focus on designing MIONs that can target and heat tumors more effectively. Furthermore, various hyperthermia enhancers should be evaluated in combination with magnetic hyperthermia, with the ultimate objective of achieving clinical feasibility.

\section{AUTHOR CONTRIBUTIONS}

DC drafted the manuscript, drew the figures and constructed the tables. DC, ML, JG, RQ, YN, FM, MJ, TD, and MK discussed the outline and critically reviewed the paper, the content, and the figures used.

\section{ACKNOWLEDGMENTS}

Special thanks to Helen Forgham for designing Figure 3. Authors are also grateful for support from the Children's Cancer Institute, which is affiliated with the University of New South Wales (UNSW Sydney) and Sydney Children's Hospital Network. DC is supported by an Australian Government Research Training Program Scholarship, and a RANZCR Genito-Urinary Fellowship Grant (supported by Tolmar Australia Pty Ltd). MK is supported by an NHMRC Principal Research Fellowship (APP1119152) and is funded by a Cancer Council New South Wales Program Grant (PG16-01). MK and TD are both funded by an Australian Research Council Centre of Excellence in Convergent Bio-Nano Science and Technology (CE140100036), and NHMRC Program Grant (APP1091261). TD is supported by an Australian Laureate Fellowship from the Australian Research Council. 
Atkinson, W. J., Brezovich, I. A., and Chakraborty, D. P. (1984). Usable frequencies in hyperthermia with thermal seeds. IEEE Trans. Biomed. Eng. 31, 70-75. doi: 10.1109/TBME.1984.325372

Balivada, S., Rachakatla, R. S., Wang, H., Samarakoon, T. N., Dani, R. K., Pyle, M., et al. (2010). A/C magnetic hyperthermia of melanoma mediated by iron(0)/iron oxide core/shell magnetic nanoparticles: a mouse study. BMC Cancer 10:119. doi: 10.1186/1471-2407-10-119

Basel, M. T., Balivada, S., Wang, H., Shrestha, T. B., Seo, G. M., Pyle, M., et al. (2012). Cell-delivered magnetic nanoparticles caused hyperthermia-mediated increased survival in a murine pancreatic cancer model. Int. J. Nanomedicine 7, 297-306. doi: 10.2147/IJN.S28344

Berdov, B. A., and Menteshashvili, G. Z. (1990). Thermoradiotherapy of patients with locally advanced carcinoma of the rectum. Int. J. Hyperthermia 6, 881-890. doi: 10.3109/02656739009140970

Blanco-Andujar, C., Ortega, D., Southern, P., Pankhurst, Q. A., and Thanh, N. T. K. (2015). High performance multi-core iron oxide nanoparticles for magnetic hyperthermia: microwave synthesis, and the role of core-to-core interactions. Nanoscale 7, 1768-1775. doi: 10.1039/C4NR06239F

Blanco-Andujar, C., Teran, F. J., and Ortega, D. (2017). "Current outlook and perspsectives on nanoparticle-mediated magnetic hyperthermia," in Iron Oxide Nanoparticles for Biomedical Applications, 1st Edn., eds L. Sophie and L. Mahmoudi (Amsterdam: Elsevier), 197-245.

Borrelli, M. J., Lepock, J. R., Frey, H. E., Lee, Y. J., and Corry, P. M. (1996). Excess protein in nuclei isolated from heat-shocked cells results from a reduced extractability of nuclear proteins. J. Cell Physiol. 167, 369-379. doi: 10.1002/ (SICI) 1097-4652(199606)167:3\&lt;369::AID-JCP1\&gt;3.0.CO;2-N

Bouras, A., Kaluzova, M., and Hadjipanayis, C. G. (2015). Radiosensitivity enhancement of radioresistant glioblastoma by epidermal growth factor receptor antibody-conjugated iron-oxide nanoparticles. J. Neuro-Oncol. 124, 13-22. doi: 10.1007/s11060-015-1807-0

Bullivant, J. P., Zhao, S., Willenberg, B. J., Kozissnik, B., Batich, C. D., and Dobson, J. (2013). Materials characterization of Feraheme/ferumoxytol and preliminary evaluation of its potential for magnetic fluid hyperthermia. Int. J. Mol. Sci. 14, 17501-17510. doi: 10.3390/ijms140917501

Chamorro, S., Gutiérrez, L., Vaquero, M. P., Verdoy, D., Salas, G., Luengo, Y., et al. (2015). Safety assessment of chronic oral exposure to iron oxide nanoparticles. Nanotechnology 26:205101. doi: 10.1088/0957-4484/26/20/205101

Cihoric, N., Tsikkinis, A., Van Rhoon, G., Crezee, H., Aebersold, D. M., Bodis, S., et al. (2015). Hyperthermia-related clinical trials on cancer treatment within the ClinicalTrials.gov registry. Int. J. Hyperthermia 31, 609-614. doi: 10.3109/02656736.2015.1040471

Clark, A. J., Wiley, D. T., Zuckerman, J. E., Webster, P., Chao, J., Lin, J., et al. (2016). CRLX101 nanoparticles localize in human tumors and not in adjacent, nonneoplastic tissue after intravenous dosing. Proc. Natl. Acad. Sci. U.S.A. 113, 3850-3854. doi: 10.1073/pnas. 1603018113

Colombo, R., Salonia, A., Leib, Z., Pavone-Macaluso, M., and Engelstein, D. (2011). Long-term outcomes of a randomized controlled trial comparing thermochemotherapy with mitomycin-C alone as adjuvant treatment for non-muscle-invasive bladder cancer (NMIBC). BJU Int. 107, 912-918. doi: 10.1111/j.1464-410X.2010.09654.x

Creixell, M., Bohorquez, A. C., Torres-Lugo, M., and Rinaldi, C. (2011). EGFRtargeted magnetic nanoparticle heaters kill cancer cells without a perceptible temperature rise. ACS Nano 5, 7124-7129. doi: 10.1021/nn201822b

Dames, P., Gleich, B., Flemmer, A., Hajek, K., Seidl, N., Wiekhorst, F., et al. (2007). Targeted delivery of magnetic aerosol droplets to the lung. Nat. Nanotechnol. 2, 495-499. doi: 10.1038/nnano.2007.217

Datta, N. R., Bose, A. K., Kapoor, H. K., and Gupta, S. (1990). Head and neck cancers: results of thermoradiotherapy versus radiotherapy. Int. J. Hyperthermia 6, 479-486. doi: 10.3109/02656739009 140944

De Haas-Kock, D. F., Buijsen, J., Pijls-Johannesma, M., Lutgens, L., Lammering, G., Van Mastrigt, G. A., et al. (2009). Concomitant hyperthermia and radiation therapy for treating locally advanced rectal cancer. Cochrane Database Syst. Rev. CD006269. doi: 10.1002/14651858.CD006269.pub2

de La Presa, P., Luengo, Y., Multigner, M., Costo, R., Morales, M. P., Rivero, G., et al. (2012). Study of heating efficiency as a function of concentration, size, and applied field in Gamma-Fe2O3 nanoparticles. J. Phys. Chem. C 116, 25602-25610. doi: 10.1021/jp310771p
DeNardo, S. J., Denardo, G. L., Natarajan, A., Miers, L. A., Foreman, A. R., Gruettner, C., et al. (2007). Thermal dosimetry predictive of efficacy of 111 InChL6 nanoparticle AMF-induced thermoablative therapy for human breast cancer in mice. J. Nucl. Med. 48, 437-444.

Dewey, W. C., Hopwood, L. E., Sapareto, S. A., and Gerweck, L. E. (1977). Cellular responses to combinations of hyperthermia and radiation. Radiology 123, 463-474. doi: 10.1148/123.2.463

Domenech, M., Marrero-Berrios, I., Torres-Lugo, M., and Rinaldi, C. (2013). Lysosomal membrane permeabilization by targeted magnetic nanoparticles in alternating magnetic fields. ACS Nano 7, 5091-5101. doi: 10.1021/nn4007048

Dunn, A. E., Dunn, D. J., Lim, M., Boyer, C., and Thanh, N. T. K. (2014). Recent developments in the design of nanomaterials for photothermal and magnetic hyperthermia induced controllable drug delivery. Nanoscience 2, 225-254. doi: 10.1039/9781849737623-00225

Dutz, S., and Hergt, R. (2013). Magnetic nanoparticle heating and heat transfer on a microscale: basic principles, realities and physical limitations of hyperthermia for tumour therapy. Int. J. Hyperther. 29, 790-800. doi: $10.3109 / 02656736.2013 .822993$

Eales, K. L., Hollinshead, K. E., and Tennant, D. A. (2016). Hypoxia and metabolic adaptation of cancer cells. Oncogenesis 5:e190. doi: 10.1038/oncsis.2015.50

Emami, B., Scott, C., Perez, C. A., Asbell, S., Swift, P., Grigsby, P., et al. (1996). Phase III study of interstitial thermoradiotherapy compared with interstitial radiotherapy alone in the treatment of recurrent or persistent human tumors: A prospectively controlled randomized study by the Radiation Therapy Oncology Group. Int. J. Radiat. Oncol. Biol. Phys. 34, 1097-1104. doi: 10.1016/0360-3016(95)02137-X

Espinosa, A., Di Corato, R., Kolosnjaj-Tabi, J., Flaud, P., Pellegrino, T., and Wilhelm, C. (2016). Duality of iron oxide nanoparticles in cancer therapy: amplification of heating efficiency by magnetic hyperthermia and photothermal bimodal treatment. ACS Nano 10, 2436-2446. doi: 10.1021/acsnano.5b07249

Franckena, M., Stalpers, L. J., Koper, P. C., Wiggenraad, R. G., Hoogenraad, W. J., Van Dijk, J. D., et al. (2008). Long-term improvement in treatment outcome after radiotherapy and hyperthermia in locoregionally advanced cervix cancer: an update of the Dutch Deep Hyperthermia Trial. Int. J. Radiat. Oncol. Biol. Phys. 70, 1176-1182. doi: 10.1016/j.ijrobp.2007.07.2348

Gao, N., Bozeman, E. N., Qian, W., Wang, L., Chen, H., Lipowska, M., et al. (2017). Tumor penetrating theranostic nanoparticles for enhancement of targeted and image-guided drug delivery into peritoneal tumors following intraperitoneal delivery. Theranostics 7, 1689-1704. doi: 10.7150/thno.18125

García-Jimeno, S., Escribano, E., Queralt, J., and Estelrich, J. (2012). External magnetic field-induced selective biodistribution of magnetoliposomes in mice. Nanoscale Res. Lett. 7: 452. doi: 10.1186/1556-276X-7-452

Gerweck, L. E., Nygaard, T. G., and Burlett, M. (1979). Response of cells to hyperthermia under acute and chronic hypoxic conditions. Cancer Res. 39, 966-972.

Ghussen, F., Nagel, K., Groth, W., Muller, J. M., and Stutzer, H. (1984). A prospective randomized study of regional extremity perfusion in patients with malignant melanoma. Ann. Surg. 200, 764-768. doi: 10.1097/00000658-198412000-00016

Gilchrist, R. K., Medal, R., Shorey, W. D., Hanselman, R. C., Parrott, J. C., and Taylor, C. B. (1957). Selective inductive heating of lymph nodes. Ann. Surg. 146, 596-606. doi: 10.1097/00000658-195710000-00007

Gonzales-Weimuller, M., Zeisberger, M., and Krishnan, K. M. (2009). Size-dependant heating rates of iron oxide nanoparticles for magnetic fluid hyperthermia. J. Magn. Magn. Mater. 321, 1947-1950. doi: $10.1016 /$ j.jmmm.2008.12.017

Gonzalez-Fernandez, M. A., Torres, T. E., Andres-Verges, M., Costo, R., De La Presa, P., Serna, C. J., et al. (2009). Magnetic nanoparticles for power absorption: optimizing size, shape and magnetic properties. J. Solid State Chem. 182, 2779-2784. doi: 10.1016/j.jssc.2009.07.047

Graczyk, H., Bryan, L. C., Lewinski, N., Suarez, G., Coullerez, G., Bowen, P., et al. (2015). Physicochemical characterization of nebulized superparamagnetic iron oxide nanoparticles (SPIONs). J. Aerosol Med. Pulm. Drug Deliv. 28, 43-51. doi: 10.1089/jamp.2013.1117

Hafström, L., Rudenstam, C. M., Blomquist, E., Ingvar, C., Jonsson, P. E. Lagerlof, B., et al. (1991). Regional hyperthermic perfusion with melphalan after surgery for recurrent malignant-melanoma of the extremities. J. Clin. Oncol. 9, 2091-2094. doi: 10.1200/JCO.1991.9.12.2091 
Hamazoe, R., Maeta, M., and Kaibara, N. (1994). Intraperitoneal thermochemotherapy for prevention of peritoneal recurrence of gastric cancer. Final results of a randomized controlled study. Cancer 73, 2048-2052. doi: $\quad 10.1002 / 1097-0142(19940415) 73: 8<2048:: A I D-C N C R 2820730806>3.0$. $\mathrm{CO} ; 2-\mathrm{Q}$

Harima, Y., Nagata, K., Harima, K., Ostapenko, V. V., Tanaka, Y., and Sawada, S. (2001). A randomized clinical trial of radiation therapy versus thermoradiotherapy in stage IIIB cervical carcinoma. Int. J. Hyperthermia 17, 97-105. doi: 10.1080/02656730010001333

Hauser, A. K., Mathias, R., Anderson, K. W., and Hilt, J. Z. (2015). The effects of synthesis method on the physical and chemical properties of dextran coated iron oxide nanoparticles. Mater. Chem. Phys. 160, 177-186. doi: 10.1016/j.matchemphys.2015.04.022

Hedayatnasab, Z., Abnisa, F., and Daud, W. M. A. W. (2017). Review on magnetic nanoparticles for magnetic nanofluid hyperthermia application. Mater. Des. 123, 174-196. doi: 10.1016/j.matdes.2017.03.036

Hergt, R., Hiergeist, R., Zeisberger, M., Schuler, D., Heyen, U., Hilger, I., et al. (2005). Magnetic properties of bacterial magnetosomes as potential diagnostic and therapeutic tools. J. Magn. Magn. Mater. 293, 80-86. doi: 10.1016/j.jmmm.2005.01.047

Hetzel, D., Strauss, W., Bernard, K., Li, Z., Urboniene, A., and Allen, L. F. (2014). A Phase, III, randomized, open-label trial of ferumoxytol compared with iron sucrose for the treatment of iron deficiency anemia in patients with a history of unsatisfactory oral iron therapy. Am. J. Hematol. 89, 646-650. doi: 10.1002/ajh.23712

Hinde, E., Thammasiraphop, K., Duong, H. T. T., Yeow, J., Karagoz, B., Boyer, C., et al. (2017). Pair correlation microscopy reveals the role of nanoparticle shape in intracellular transport and site of drug release. Nat. Nanotechnol. 12, 81-89. doi: $10.1038 /$ nnano. 2016.160

Houlding, T. K., and Rebrov, E. V. (2012). Application of alternative energy forms in catalytic reactor engineering. Green Process Synth. 1, 19-31. doi: 10.1515/greenps-2011-0502

Howard, C. B., Fletcher, N., Houston, Z. H., Fuchs, A. V., Boase, N. R. B., Simpson, J. D., et al. (2016). Overcoming instability of antibody-nanomaterial conjugates: next generation targeted nanomedicines using bispecific antibodies. Adv. Healthc. Mater. 5, 2055-2068. doi: 10.1002/adhm.201600263

Huang, F. K., Chen, W. C., Lai, S. F., Liu, C. J., Wang, C. L., Wang, C. H., et al. (2010). Enhancement of irradiation effects on cancer cells by cross-linked dextran-coated iron oxide (CLIO) nanoparticles. Phys. Med. Biol. 55, 469-482. doi: 10.1088/0031-9155/55/2/009

Huang, H. S., and Hainfeld, J. F. (2013). Intravenous magnetic nanoparticle cancer hyperthermia. Int. J. Nanomedicine 8, 2521-2532. doi: 10.2147/IJN.S43770

Huang, S., Wang, S. Y., Gupta, A., Borca-Tasciuc, D. A., and Salon, S. J. (2012). On the measurement technique for specific absorption rate of nanoparticles in an alternating electromagnetic field. Meas. Sci. Technol. 23, 1-6. doi: 10.1088/0957-0233/23/3/035701

Huilgol, N. G., Gupta, S., and Sridhar, C. R. (2010). Hyperthermia with radiation in the treatment of locally advanced head and neck cancer: a report of randomized trial. J. Cancer Res. Ther. 6, 492-496. doi: 10.4103/0973-1482.77101

Ilinskaya, A. N., and Dobrovolskaia, M. A. (2013). Nanoparticles and the blood coagulation system. Part II: safety concerns. Nanomedicine 8, 969-981. doi: $10.2217 / \mathrm{nnm} .13 .49$

Issels, R. D., Lindner, L. H., Verweij, J., Wust, P., Reichardt, P., Schem, B. C., et al. (2010). Neo-adjuvant chemotherapy alone or with regional hyperthermia for localised high-risk soft-tissue sarcoma: a randomised phase 3 multicentre study. Lancet Oncol. 11, 561-570. doi: 10.1016/S1470-2045(10)70071-1

Ito, A., Saito, H., Mitobe, K., Minamiya, Y., Takahashi, N., Maruyama, K., et al. (2009). Inhibition of heat shock protein 90 sensitizes melanoma cells to thermosensitive ferromagnetic particle-mediated hyperthermia with low Curie temperature. Cancer Sci. 100, 558-564. doi: 10.1111/j.1349-7006.2008. 01072.x

Iyer, A. K., Khaled, G., Fang, J., and Maeda, H. (2006). Exploiting the enhanced permeability and retention effect for tumor targeting. Drug Discov. Today 11, 812-818. doi: 10.1016/j.drudis.2006.07.005

Jang, J. T., Nah, H., Lee, J. H., Moon, S. H., Kim, M. G., and Cheon, J. (2009). Critical Enhancements of MRI contrast and hyperthermic effects by dopantcontrolled magnetic nanoparticles. Angew. Chem. Int. Ed. 48, 1234-1238. doi: 10.1002/anie.200805149
Jeun, M., Lee, S., Kang, J. K., Tomitaka, A., Kang, K. W., Kim, Y. I., et al. (2012). Physical limits of pure superparamagnetic $\mathrm{Fe}_{3} \mathrm{O}_{4}$ nanoparticles for a local hyperthermia agent in nanomedicine. Appl. Phys. Lett. 100:092406. doi: $10.1063 / 1.3689751$

Johannsen, M., Gneveckow, U., Eckelt, L., Feussner, A., Waldofner, N., Scholz, R., et al. (2005). Clinical hyperthermia of prostate cancer using magnetic nanoparticles: presentation of a new interstitial technique. Int. J. Hyperthermia 21, 637-647. doi: 10.1080/02656730500158360

Johannsen, M., Gneveckow, U., Taymoorian, K., Thiesen, B., Waldofner N., Scholz, R., et al. (2007a). Morbidity and quality of life during thermotherapy using magnetic nanoparticles in locally recurrent prostate cancer: results of a prospective phase I trial. Int. J. Hyperthermia 23, 315-323. doi: 10.1080/02656730601175479

Johannsen, M., Gneveckow, U., Thiesen, B., Taymoorian, K., Cho, C. H., Waldofner, N., et al. (2007b). Thermotherapy of prostate cancer using magnetic nanoparticles: feasibility, imaging, and three-dimensional temperature distribution. Eur. Urol. 52, 1653-1661. doi: 10.1016/j.eururo.2006.11.023

Johannsen, M., Thiesen, B., Wust, P., and Jordan, A. (2010). Magnetic nanoparticle hyperthermia for prostate cancer. Int. J. Hyperthermia 26, 790-795. doi: 10.3109/02656731003745740

Jones, E. L., Oleson, J. R., Prosnitz, L. R., Samulski, T. V., Vujaskovic, Z., Yu, D., et al. (2005). Randomized trial of hyperthermia and radiation for superficial tumors. J. Clin. Oncol. 23, 3079-3085. doi: 10.1200/JCO.2005.05.520

Jordan, A., Scholz, R., Maier-Hauff, K., Johannsen, M., Wust, P., Nadobny, J., et al. (2001). Presentation of a new magnetic field therapy system for the treatment of human solid tumors with magnetic fluid hyperthermia. J. Magn. Magn. Mater. 225, 118-126. doi: 10.1016/S0304-8853(00)01239-7

Jordan, A., Scholz, R., Wust, P., Fahling, H., and Felix, R. (1999). Magnetic fluid hyperthermia (MFH): cancer treatment with AC magnetic field induced excitation of biocompatible superparamagnetic nanoparticles. J. Magn. Magn. Mater. 201, 413-419. doi: 10.1016/S0304-8853(99)00088-8

Jordan, A., Wust, P., Fähling, H., John, W., Hinz, A., and Felix, R. (1993). Inductive heating of ferrimagnetic particles and magnetic fluids - physical evaluation of their potential for hyperthermia. Int. J. Hyperthermia 9, 51-68. doi: 10.3109/02656739309061478

Kallumadil, M., Tada, M., Nakagawa, T., Abe, M., Southern, P., and Pankhurst, Q. A. (2009). Suitability of commercial colloids for magnetic hyperthermia. J. Magn. Magn. Mater. 321, 3650-3651. doi: 10.1016/j.jmmm.2009.06.069

Kampinga, H. H., and Dikomey, E. (2001). Hyperthermic radiosensitization: mode of action and clinical relevance. Int. J. Radiat. Biol. 77, 399-408. doi: 10.1080/09553000010024687

Kampinga, H. H., Dynlacht, J. R., and Dikomey, E. (2004). Mechanism of radiosensitization by hyperthermia $\left(43^{\circ} \mathrm{C}\right)$ as derived from studies with DNA repair defective mutant cell lines. Int. J. Hyperthermia 20, 131-139. doi: 10.1080/02656730310001627713

Khoei, S., Mahdavi, S. R., Fakhimikabir, H., Shakeri-Zadeh, A., and Hashemian, A. (2014). The role of iron oxide nanoparticles in the radiosensitization of human prostate carcinoma cell line DU145 at megavoltage radiation energies. Int. J. Radiat. Biol. 90, 351-356. doi: 10.3109/09553002.2014.888104

Kim, D. H., Li, W., Chen, J., Zhang, Z., Green, R. M., Huang, S., et al. (2016). Multimodal imaging of nanocomposite microspheres for transcatheter intraarterial drug delivery to liver tumors. Sci. Rep. 6:29653. doi: 10.1038/srep 29653

Kirschning, A., Kupracz, L., and Hartwig, J. (2012). New synthetic opportunities in miniaturized flow reactors with inductive heating. Chem. Lett. 41, 562-570. doi: $10.1246 /$ cl.2012.562

Kitamura, K., Kuwano, H., Watanabe, M., Nozoe, T., Yasuda, M., Sumiyoshi, K., et al. (1995). Prospective randomized study of hyperthermia combined with chemoradiotherapy for esophageal carcinoma. J. Surg. Oncol. 60, 55-58. doi: $10.1002 /$ jso.2930600111

Klein, S., Sommer, A., Distel, L. V., Neuhuber, W., and Kryschi, C. (2012). Superparamagnetic iron oxide nanoparticles as radiosensitizer via enhanced reactive oxygen species formation. Biochem. Biophys. Res. Commun. 425, 393-397. doi: 10.1016/j.bbrc.2012.07.108

Koops, H. S., Vaglini, M., Suciu, S., Kroon, B. B. R., Thompson, J. F., Gohl, J., et al. (1998). Prophylactic isolated limb perfusion for localized, high-risk limb melanoma: results of a multicenter randomized phase III trial. J. Clin. Oncol. 16, 2906-2912. doi: 10.1200/JCO.1998.16.9.2906 
Lartigue, L., Innocenti, C., Kalaivani, T., Awwad, A., Duque, M. D. S., Guari, Y., et al. (2011). Water-dispersible sugar-coated iron oxide nanoparticles. An evaluation of their relaxometric and magnetic hyperthermia properties. J. Am. Chem. Soc. 133, 10459-10472. doi: 10.1021/ja111448t

Le Fèvre, R., Durand-Dubief, M., Chebbi, I., Mandawala, C., Lagroix, F., Valet, J. P., et al. (2017). Enhanced antitumor efficacy of biocompatible magnetosomes for the magnetic hyperthermia treatment of glioblastoma. Theranostics 7 , 4618-4631. doi: 10.7150/thno.18927

Lee, I. J., Ahn, C. H., Cha, E. J., Chung, I. J., Chung, J. W., and Kim, Y. I. (2013). Improved drug targeting to liver tumors after intra-arterial delivery using superparamagnetic iron oxide and iodized oil: preclinical study in a rabbit model. Invest. Radiol. 48, 826-833. doi: 10.1097/RLI.0b013e31829c13ef

Lee, I. J., Park, J. Y., Kim, Y. I., Lee, Y. S., Jeong, J. M., Kim, J., et al. (2017). Image-based analysis of tumor localization after intra-arterial delivery of technetium-99m-labeled SPIO using SPECT/CT and MRI. Mol. Imaging 16:1536012116689001. doi: 10.1177/1536012116689001

Lepock, J. R. (2005a). How do cells respond to their thermal environment? Int. J. Hyperthermia 21, 681-687. doi: 10.1080/02656730500307298

Lepock, J. R. (2005b). Measurement of protein stability and protein denaturation in cells using differential scanning calorimetry. Methods 35, 117-125. doi: 10.1016/j.ymeth.2004.08.002

Leuenberger, P., Ganscha, S., Kahraman, A., Cappelletti, V., Boersema, P. J., Von Mering, C., et al. (2017). Cell-wide analysis of protein thermal unfolding reveals determinants of thermostability. Science 355:eaai7825. doi: $10.1126 /$ science.aai7825

Liu, G., Gao, J. H., Ai, H., and Chen, X. Y. (2013). Applications and potential toxicity of magnetic iron oxide nanoparticles. Small 9, 1533-1545. doi: 10.1002/smll.201201531

Liu, X. L., Fan, H. M., Yi, J. B., Yang, Y., Choo, E. S. G., Xue, J. M., et al. (2012). Optimization of surface coating on $\mathrm{Fe}_{3} \mathrm{O}_{4}$ nanoparticles for high performance magnetic hyperthermia agents. J. Mater. Chem. 22, 8235-8244. doi: $10.1039 / \mathrm{c} 2 \mathrm{jm} 30472 \mathrm{~d}$

Liu, X. L., Yang, Y., Ng, C. T., Zhao, L. Y., Zhang, Y., Bay, B. H., et al. (2015). Magnetic vortex nanorings: a new class of hyperthermia agent for highly efficient in vivo regression of tumors. Adv. Mater. 27, 1939-44. doi: 10.1002/adma.201405036

Lu, M., Cohen, M. H., Rieves, D., and Pazdur, R. (2010). FDA report: ferumoxytol for intravenous iron therapy in adult patients with chronic kidney disease. Am. J. Hematol. 85, 315-319. doi: 10.1002/ajh.21656

Lutgens, L., Van Der Zee, J., Pijls-Johannesma, M., De Haas-Kock, D. F., Buijsen, J., Mastrigt, G. A., et al. (2010). Combined use of hyperthermia and radiation therapy for treating locally advanced cervix carcinoma. Cochrane Database Syst. Rev. CD006377. doi: 10.1002/14651858.CD006377.pub2

Ma, P., Luo, Q., Chen, J., Gan, Y., Du, J., Ding, S., et al. (2012). Intraperitoneal injection of magnetic $\mathrm{Fe}_{3} \mathrm{O}_{4}$-nanoparticle induces hepatic and renal tissue injury via oxidative stress in mice. Int. J. Nanomedicine 7, 4809-4818. doi: $10.2147 / \mathrm{IJN}$.S34349

Magforce (2013). Available online at: https://www.drks.de/drks_web/navigate. do?navigationId=trial.HTML\&TRIAL_ID=DRKS00005476 [Accessed May 29 2018].

Magforce (2018). “Annual Report 2017: Important Cornerstones Laid for Two Pillar Strategy", Available online at: http://magforce.de/fileadmin/magforce/5_presse/ finanzberichte/Geschaeftsbericht_2017/magforce_gb17_e_s.pdf

Mahmoudi, K., Bouras, A., Bozec, D., Ivkov, R., and Hadjipanayis, C. (2018). Magnetic hyperthermia therapy for the treatment of glioblastoma: a review of the therapy's history, efficacy and application in humans. Int. J. Hyperthermia. doi: 10.1080/02656736.2018.1430867. [Epub ahead of print].

Maier-Hauff, K., Rothe, R., Scholz, R., Gneveckow, U., Wust, P., Thiesen, B., et al. (2007). Intracranial thermotherapy using magnetic nanoparticles combined with external beam radiotherapy: results of a feasibility study on patients with glioblastoma multiforme. J. Neuro-Oncol. 81, 53-60. doi: 10.1007/s11060-006-9195-0

Maier-Hauff, K., Ulrich, F., Nestler, D., Niehoff, H., Wust, P., Thiesen, B., et al. (2011). Efficacy and safety of intratumoral thermotherapy using magnetic iron-oxide nanoparticles combined with external beam radiotherapy on patients with recurrent glioblastoma multiforme. J. Neuro-Oncol. 103, 317-324. doi: 10.1007/s11060-010-0389-0
Marchal, C., Anghileri, L. J., Escanye, M. C., and Robert, J. (1986). Hyperthermia and cytotoxic drugs. Possible use of lanthanum as a potentiator of hyperthermia. Int. J. Hyperthermia 2, 83-92. doi: 10.3109/02656738609019997

Martinez-Boubeta, C., Simeonidis, K., Makridis, A., Angelakeris, M., Iglesias, O., Guardia, P., et al. (2013). Learning from nature to improve the heat generation of iron-oxide nanoparticles for magnetic hyperthermia applications. Sci. Rep. 3:1652. doi: $10.1038 /$ srep 01652

Mello, P. D., Bian, S., Savio, L. E. B., Zhang, H. H., Zhang, J. P., Junger, W., et al. (2017). Hyperthermia and associated changes in membrane fluidity potentiate P2X7 activation to promote tumor cell death. Oncotarget 8, 67254-67268. doi: 10.18632/oncotarget.18595

Milowsky, M. I., Galsky, M. D., Morris, M. J., Crona, D. J., George, D. J., Dreicer, R., et al. (2016). Phase $1 / 2$ multiple ascending dose trial of the prostate-specific membrane antigen-targeted antibody drug conjugate MLN2704 in metastatic castration-resistant prostate cancer. Urol. Oncol. 34, 530.e515-530.e21. doi: 10.1016/j.urolonc.2016.07.005

Nair, B. G., Nagaoka, Y., Morimoto, H., Yoshida, Y., Maekawa, T., and Kumar, D. S. (2010). Aptamer conjugated magnetic nanoparticles as nanosurgeons. Nanotechnology 21:455102. doi: 10.1088/0957-4484/21/45/455102

Namiki, Y., Namiki, T., Yoshida, H., Ishii, Y., Tsubota, A., Koido, S., et al. (2009). A novel magnetic crystal-lipid nanostructure for magnetically guided in vivo gene delivery. Nat. Nanotechnol. 4, 598-606. doi: 10.1038/nnano.2009.202

Nemati, Z., Alonso, J., Martinez, L. M., Khurshid, H., Garaio, E., Garcia, J. A., et al. (2016). Enhanced magnetic hyperthermia in iron oxide nanooctopods: size and anisotropy effects. J. Phys. Chem. C 120, 8370-8379. doi: 10.1021/acs.jpcc.6b01426

Nieskoski, M. D., and Trembly, B. S. (2014). Comparison of a single optimized coil and a helmholtz pair for magnetic nanoparticle hyperthermia. IEEE T Bio-Med. Eng. 61, 1642-1650. doi: 10.1109/TBME.2013.2296231

Obaidat, I. M., Issa, B., and Haik, Y. (2015). Magnetic properties of magnetic nanoparticles for efficient hyperthermia. Nanomaterials 5, 63-89. doi: $10.3390 /$ nano5010063

Oliveira, T. R., Stauffer, P. R., Lee, C. T., Landon, C. D., Etienne, W., Ashcraft, K. A., et al. (2013). Magnetic fluid hyperthermia for bladder cancer: a preclinical dosimetry study. Int. J. Hyperthermia 29, 835-844. doi: $10.3109 / 02656736.2013 .834384$

Overgaard, J. (1984). Formula to estimate the thermal enhancement ratio of a single simultaneous hyperthermia and radiation treatment. Acta Radiol. Oncol. 23, 135-139. doi: 10.3109/02841868409136001

Overgaard, J., Gonzalez Gonzalez, D., Hulshof, M. C., Arcangeli, G., Dahl, O., Mella, O., et al. (1996). Hyperthermia as an adjuvant to radiation therapy of recurrent or metastatic malignant melanoma. A multicentre randomized trial by the European Society for Hyperthermic Oncology. Int. J. Hyperthermia 12, 3-20. doi: 10.3109/02656739609023685

Peer, A. J., Grimm, M. J., Zynda, E. R., and Repasky, E. A. (2010). Diverse immune mechanisms may contribute to the survival benefit seen in cancer patients receiving hyperthermia. Immunol. Res. 46, 137-154. doi: 10.1007/s12026-009-8115-8

Peng, H., Tang, J., Zheng, R., Guo, G., Dong, A., Wang, Y., et al. (2017). Nucleartargeted multifunctional magnetic nanoparticles for photothermal therapy. Adv. Healthc. Mater. 6:1601289. doi: 10.1002/adhm.201601289

Perez, C. A., Pajak, T., Emami, B., Hornback, N. B., Tupchong, L., and Rubin, P. (1991). Randomized phase III study comparing irradiation and hyperthermia with irradiation alone in superficial measurable tumors. Final report by the radiation therapy oncology group. Am. J. Clin. Oncol. 14, 133-141. doi: 10.1097/00000421-199104000-00008

Phong, P. T., Nam, P. H., Manh, D. H., and Lee, I. J. (2017). $\mathrm{Mn}_{0.5} \mathrm{Zn}_{0.5} \mathrm{Fe}_{2} \mathrm{O}_{4}$ nanoparticles with high intrinsic loss power for hyperthermia therapy. J. Magn. Magn. Mater. 433, 76-83. doi: 10.1016/j.jmmm.2017.03.001

Plan Sangnier, A., Preveral, S., Curcio, A., Silva, A. K. A., Lefèvre, C. T., et al. and Wilhelm, C. (2018). Targeted thermal therapy with genetically engineered magnetite magnetosomes@RGD: Photothermia is far more efficient than magnetic hyperthermia. J. Control. Release 279, 271-281. doi: 10.1016/j.jconrel.2018.04.036

Qiu, Y., Tong, S., Zhang, L., Sakurai, Y., Myers, D. R., Hong, L., et al. (2017). Magnetic forces enable controlled drug delivery by disrupting endothelial cell-cell junctions. Nat. Commun. 8:15594. doi: 10.1038/ncomms15594 
Rau, B., Wust, P., Tilly, W., Gellermann, J., Harder, C., Riess, H., et al. (2000). Preoperative radiochemotherapy in locally advanced or recurrent rectal cancer: regional radiofrequency hyperthermia correlates with clinical parameters. Int. J. Radiat. Oncol. Biol. Phys. 48, 381-391. doi: 10.1016/S0360-3016(00)00650-7

Reddy, L. H., Arias, J. L., Nicolas, J., and Couvreur, P. (2012). Magnetic nanoparticles: design and characterization, toxicity and biocompatibility, pharmaceutical and biomedical applications. Chem. Rev. 112, 5818-5878. doi: $10.1021 / \mathrm{cr} 300068 \mathrm{p}$

Richter, K., Haslbeck, M., and Buchner, J. (2010). The heat shock response: life on the verge of death. Mol. Cell 40, 253-266. doi: 10.1016/j.molcel.2010.10.006

Rivas, J., Banobre-Lopez, M., Pineiro-Redondo, Y., Rivas, B., and Lopez-Quintela, M. A. (2012). Magnetic nanoparticles for application in cancer therapy. J. Magn. Magn. Mater. 324, 3499-3502. doi: 10.1016/j.jmmm.2012.02.075

Roizin-Towle, L., and Pirro, J. P. (1991). The response of human and rodent cells to hyperthermia. Int. J. Radiat. Oncol. Biol. Phys. 20, 751-756. doi: 10.1016/0360-3016(91)90018-Y

Rosenblum, D., Joshi, N., Tao, W., Karp, J. M., and Peer, D. (2018). Progress and challenges towards targeted delivery of cancer therapeutics. Nat. Commun. 9:1410. doi: 10.1038/s41467-018-03705-y

Rosensweig, R. E. (2002). Heating magnetic fluid with alternating magnetic field. J. Magn. Magn. Mater. 252, 370-374. doi: 10.1016/S0304-8853(02)00706-0

Ruta, S., Chantrell, R., and Hovorka, O. (2015). Unified model of hyperthermia via hysteresis heating in systems of interacting magnetic nanoparticles. Sci. Rep. 5:9090. doi: 10.1038/srep09090

Salas, G., Camarero, J., Cabrera, D., Takacs, H., Varela, M., Ludwig, R., et al. (2014). Modulation of magnetic heating via dipolar magnetic interactions in monodisperse and crystalline iron oxide nanoparticles. J. Phys. Chem. C 118, 19985-19994. doi: 10.1021/jp5041234

Schilling, D., Kühnel, A., Konrad, S., Tetzlaff, F., Bayer, C., Yaglom, J., et al. (2015). Sensitizing tumor cells to radiation by targeting the heat shock response. Cancer Lett. 360, 294-301. doi: 10.1016/j.canlet.2015.02.033

Shah, A., and Dobrovolskaia, M. A. (2018). Immunological effects of iron oxide nanoparticles and iron-based complex drug formulations: therapeutic benefits, toxicity, mechanistic insights, and translational considerations. Nanomed. Nanotechnol. 14, 977-990. doi: 10.1016/j.nano.2018. 01.014

Sharma, S., Singhal, S., Sandhu, A. P., Ghoshal, S., Gupta, B. D., and Yadav, N. S. (1991). Local thermo-radiotherapy in carcinoma cervix: improved local control versus increased incidence of distant metastasis. Asia Oceania J. Obstet. Gynaecol. 17, 5-12. doi: 10.1111/j.1447-0756.1991.tb00244.x

Sneed, P. K., Stauffer, P. R., Mcdermott, M. W., Diederich, C. J., Lamborn, K. R., Prados, M. D., et al. (1998). Survival benefit of hyperthermia in a prospective randomized trial of brachytherapy boost +/- hyperthermia for glioblastoma multiforme. Int. J. Radiat. Oncol. Biol. Phys. 40, 287-295. doi: 10.1016/S0360-3016(97)00731-1

Song, C. W., Park, H. J., Lee, C. K., and Griffin, R. (2005). Implications of increased tumor blood flow and oxygenation caused by mild temperature hyperthermia in tumor treatment. Int. J. Hyperthermia 21, 761-767. doi: $10.1080 / 02656730500204487$

Song, C. W., Shakil, A., Osborn, J. L., and Iwata, K. (1996). Tumour oxygenation is increased by hyperthermia at mild temperatures. Int. J. Hyperthermia 12, 367-373. doi: 10.3109/02656739609022525

Song, M. J., Zhang, Y., Hu, S. L., Song, L. N., Dong, J. L., Chen, Z. P., et al. (2012). Influence of morphology and surface exchange reaction on magnetic properties of monodisperse magnetite nanoparticles. Colloid Surface A 408, 114-121. doi: 10.1016/j.colsurfa.2012.05.039

Sugimachi, K., Kuwano, H., Ide, H., Toge, T., Saku, M., and Oshiumi, Y. (1994). Chemotherapy combined with or without hyperthermia for patients with oesophageal carcinoma: a prospective randomized trial. Int. J. Hyperthermia 10, 485-493. doi: 10.3109/02656739409009352

Suriyanto, Ng, E. Y., and Kumar, S.D. (2017). Physical mechanism and modeling of heat generation and transfer in magnetic fluid hyperthermia through Neelian and Brownian relaxation: a review. Biomed. Eng. Online 16:36. doi: $10.1186 / \mathrm{s} 12938-017-0327-\mathrm{x}$

Suto, M., Hirota, Y., Mamiya, H., Fujita, A., Kasuya, R., Tohji, K., et al. (2009). Heat dissipation mechanism of magnetite nanoparticles in magnetic fluid hyperthermia. J. Magn. Magn. Mater. 321, 1493-1496. doi: $10.1016 /$ j.jmmm.2009.02.070
Taratula, O., Dani, R. K., Schumann, C., Xu, H., Wang, A., Song, H., et al. (2013). Multifunctional nanomedicine platform for concurrent delivery of chemotherapeutic drugs and mild hyperthermia to ovarian cancer cells. Int. J. Pharm. 458, 169-180. doi: 10.1016/j.ijpharm.2013.09.032

Tewes, F., Ehrhardt, C., and Healy, A. M. (2014). Superparamagnetic iron oxide nanoparticles (SPIONs)-loaded Trojan microparticles for targeted aerosol delivery to the lung. Eur. J. Pharm. Biopharm. 86, 98-104. doi: 10.1016/j.ejpb.2013.09.004

Thomas, R. G., Moon, M. J., Lee, H., Sasikala, A. R., Kim, C. S., Park, I. K., et al. (2015). Hyaluronic acid conjugated superparamagnetic iron oxide nanoparticle for cancer diagnosis and hyperthermia therapy. Carbohydr. Polym. 131, 439-446. doi: 10.1016/j.carbpol.2015.06.010

Toraya-Brown, S., Sheen, M. R., Baird, J. R., Barry, S., Demidenko, E., Turk, M. J., et al. (2013). Phagocytes mediate targeting of iron oxide nanoparticles to tumors for cancer therapy. Integr. Biol. 5, 159-171. doi: 10.1039/C2IB20180A

Tse, B. W., Cowin, G. J., Soekmadji, C., Jovanovic, L., Vasireddy, R. S., Ling, M. T., et al. (2015). PSMA-targeting iron oxide magnetic nanoparticles enhance MRI of preclinical prostate cancer. Nanomedicine 10, 375-386. doi: $10.2217 / \mathrm{nnm} .14 .122$

Urano, M., Kuroda, M., and Nishimura, Y. (1999). For the clinical application of thermochemotherapy given at mild temperatures. Int. J. Hyperthermia 15, 79-107. doi: 10.1080/026567399285765

Valdagni, R., Amichetti, M., and Pani, G. (1988). Radical radiation alone versus radical radiation plus microwave hyperthermia for N3 (TNM-UICC) neck nodes: a prospective randomized clinical trial. Int. J. Radiat. Oncol. Biol. Phys. 15, 13-24. doi: 10.1016/0360-3016(88)90341-0

van der Zee, J. (2002). Heating the patient: a promising approach? Ann. Oncol. 13, 1173-1184. doi: 10.1093/annonc/mdf280

Van Der Zee, J., Gonzalez Gonzalez, D., Van Rhoon, G. C., Van Dijk, J. D., Van Putten, W. L., and Hart, A. A. (2000). Comparison of radiotherapy alone with radiotherapy plus hyperthermia in locally advanced pelvic tumours: a prospective, randomised, multicentre trial. Dutch. Deep. Hyperthermia Group Lancet 355, 1119-1125. doi: 10.1016/S0140-6736(00)02059-6

Van Landeghem, F. K., Maier-Hauff, K., Jordan, A., Hoffmann, K. T., Gneveckow, U., Scholz, R., et al. (2009). Post-mortem studies in glioblastoma patients treated with thermotherapy using magnetic nanoparticles. Biomaterials 30, 52-57. doi: 10.1016/j.biomaterials.2008.09.044

van Leeuwen, C. M., Oei, A. L., Chin, K. W. T. K., Crezee, J., Bel, A., Westermann, A. M., et al. (2017). A short time interval between radiotherapy and hyperthermia reduces in-field recurrence and mortality in women with advanced cervical cancer. Radiat. Oncol. 12:75. doi: 10.1186/s13014-017-0813-0

Vernon, C. C., Hand, J. W., Field, S. B., Machin, D., Whaley, J. B., Van Der Zee, J., et al. (1996). Radiotherapy with or without hyperthermia in the treatment of superficial localized breast cancer: results from five randomized controlled trials. International Collaborative Hyperthermia Group. Int. J. Radiat. Oncol. Biol. Phys. 35, 731-744. doi: 10.1016/0360-3016(96) 00154-X

Verwaal, V. J., Bruin, S., Boot, H., Van Slooten, G., and Van Tinteren, H. (2008). 8-year follow-up of randomized trial: cytoreduction and hyperthermic intraperitoneal chemotherapy versus systemic chemotherapy in patients with peritoneal carcinomatosis of colorectal cancer. Ann. Surg. Oncol. 15, 2426-2432. doi: 10.1245/s10434-008-9966-2

Wei, Y., Zhao, M. Z., Yang, F., Mao, Y., Xie, H., and Zhou, Q. B. (2016). Iron overload by superparamagnetic iron oxide nanoparticles is a high risk factor in cirrhosis by a systems toxicology assessment. Sci. Rep. 6:29110. doi: $10.1038 /$ srep29110

Wildeboer, R. R., Southern, P., and Pankhurst, Q. A. (2014). On the reliable measurement of specific absorption rates and intrinsic loss parameters in magnetic hyperthermia materials. J. Phys. D Appl. Phys. 47:495003. doi: $10.1088 / 0022-3727 / 47 / 49 / 495003$

Wu, H., Yin, J. J., Wamer, W. G., Zeng, M. Y., and Lo, Y. M. (2014). Reactive oxygen species-related activities of nano-iron metal and nano-iron oxides. J. Food Drug Anal. 22, 86-94. doi: 10.1016/j.jfda.2014.01.007

Wust, P., Hildebrandt, B., Sreenivasa, G., Rau, B., Gellermann, J., Riess, H., et al. (2002). Hyperthermia in combined treatment of cancer. Lancet Oncol. 3 , 487-497. doi: 10.1016/S1470-2045(02)00818-5

Xu, C., Shi, S. X., Feng, L. Z., Chen, F., Graves, S. A., Ehlerding, E. B., et al. (2016), Long circulating reduced graphene oxide-iron oxide nanoparticles for efficient 
tumor targeting and multimodality imaging. Nanoscale 8, 12683-12692. doi: 10.1039/C5NR09193D

Yang, R., Tang, Q. S., Miao, F. Q., An, Y. L., Li, M. F., Han, Y., et al. (2015). Inhibition of heat-shock protein 90 sensitizes liver cancer stemlike cells to magnetic hyperthermia and enhances anti-tumor effect on hepatocellular carcinoma-burdened nude mice. Int. J. Nanomedicine 10, 7345-7358. doi: 10.2147/IJN.S93758

Zhang, J., Dewilde, A. H., Chinn, P., Foreman, A., Barry, S., Kanne, D., et al. (2011). Herceptin-directed nanoparticles activated by an alternating magnetic field selectively kill HER-2 positive human breast cells in vitro via hyperthermia. Int. J. Hyperthermia 27, 682-697. doi: 10.3109/02656736.2011. 609863

Zhu, W. G., Antoku, S., Kura, S., Aramaki, R., Nakamura, K., and Sasaki, H. (1995). Enhancement of hyperthermic killing in L5178y cells by protease inhibitors. Cancer Res. 55, 739-742.
Zuckerman, J. E., and Davis, M. E. (2015). Clinical experiences with systemically administered siRNA-based therapeutics in cancer. Nat. Rev. Drug Discov. 14, 843-856. doi: 10.1038/nrd4685

Conflict of Interest Statement: The authors declare that the research was conducted in the absence of any commercial or financial relationships that could be construed as a potential conflict of interest.

Copyright (c) 2018 Chang, Lim, Goos, Qiao, Ng, Mansfeld, Jackson, Davis and Kavallaris. This is an open-access article distributed under the terms of the Creative Commons Attribution License (CC BY). The use, distribution or reproduction in other forums is permitted, provided the original author(s) and the copyright owner(s) are credited and that the original publication in this journal is cited, in accordance with accepted academic practice. No use, distribution or reproduction is permitted which does not comply with these terms. 